Landslides (2019) 16:533-549

DOI 10.1007/s10346-018-1079-9

Received: 15 March 2018

Accepted: 9 October 2018

Published online: 22 November 2018

(c) The Author(s) 2018

\author{
Alton C. Byers - David R. Rounce - Dan H. Shugar · Jonathan M. Lala · Elizabeth A. Byers · \\ Dhananjay Regmi
}

\section{A rockfall-induced glacial lake outburst flood, Upper Barun Valley, Nepal}

\begin{abstract}
On April 20, 2017, a flood from the Barun River, MakaluBarun National Park, eastern Nepal formed a 2-3-km-long lake at its confluence with the Arun River as a result of blockage by debris. Although the lake drained spontaneously the next day, it caused nationwide concern and triggered emergency responses. We identified the primary flood trigger as a massive rockfall from the northwest face of Saldim Peak $(6388 \mathrm{~m})$ which fell approximately $570 \mathrm{~m}$ down to the unnamed glacier above Langmale glacial lake, causing a massive dust cloud and hurricane-force winds. The impact also precipitated an avalanche, carrying blocks of rock and ice up to $5 \mathrm{~m}$ in diameter that plummeted a further $630 \mathrm{~m}$ down into Langmale glacial lake, triggering a glacial lake outburst flood (GLOF). The flood carved steep canyons, scoured the river's riparian zone free of vegetation, and deposited sediment, debris, and boulders throughout much of the river channel from the settlement of Langmale to the settlement of Yangle Kharka about $6.5 \mathrm{~km}$ downstream. Peak discharge was estimated at $4400 \pm 1800 \mathrm{~m}^{3} \mathrm{~s}^{-1}$, and total flood volume was estimated at $1.3 \times 10^{6} \mathrm{~m}^{3}$ of water. This study highlights the importance of conducting integrated field studies of recent catastrophic events as soon as possible after they occur, in order to best understand the complexity of their triggering mechanisms, resultant impacts, and risk reduction management options.
\end{abstract}

Keywords Glacial lakes · Rockfall · Avalanche · Glacial lake outburst floods $\cdot$ Downstream impacts

\section{Introduction}

Since the early 1960s, hundreds of new glacial lakes have formed in the Nepal Himalaya as a result of warming trends and glacial retreat. These lakes can be potentially hazardous in the event that a glacial lake outburst flood occurs, which suddenly releases the stored water. Triggering mechanisms, most often ice avalanches entering the lake (Emmer and Cochachin 2013; Falatkova 2016; Nie et al. 2017), can create a surge wave that breaches the unconsolidated terminal moraine dam. Other potential trigger mechanisms include "displacement waves from rockfalls, moraine failure due to dam settlement and/or piping, the degradation of an ice-cored moraine, seismic activity, or the rapid input of water from extreme events or from an outburst flood from a glacial lake located upstream" (Rounce et al. 2017a). As of 2011, 24 known glacial lake outburst flood (GLOF) events had been recorded for Nepal, the majority occurring since the 1960 s (ICIMOD 2011). At least five additional five GLOFs or glacier-related floods have been reported since that time, i.e., the Seti Kosi (river) flood of May 5, 2012 (Kargel et al. 2013), the Langmoche lake flood of April 25, 2015 (Byers et al. 2017), the Lhotse glacier outburst floods of 2015 and 2016 (Rounce et al. 2017b), and the April 20, 2017 Langmale glacial lake flood discussed in the current paper.
Since the 1980s, a number of field-based studies concerned with the causes and impacts of contemporary GLOFs have been conducted in Nepal (e.g., Vuichard and Zimmermann 1987; Cenderelli and Wohl 2001; Lamsal et al. 2015; Byers et al. 2017). Nearly all have taken place years to decades after the event, and there is often uncertainty as to the actual flood triggering mechanisms involved (e.g., Lamsal et al. 2015). This comparatively small number of field-based studies is likely related to the expense, difficult working conditions, and remoteness of the high mountain regions in which Himalayan GLOFs have occurred. These studies, supported and enhanced by remote sensing and laboratory analyses, are nevertheless important for advancing our understanding of the various and complex triggering mechanisms that can cause a flood and for enabling the development of effective hazard management and risk reduction methods for downstream communities and infrastructure. The following study discusses our findings regarding the source, cause, and impact of a GLOF that occurred on April 20, 2017 in the remote Barun valley, Makalu-Barun National Park, eastern Nepal.

\section{Background}

At 4:00 p.m. on April 20, 2017, a flood from the Barun River, Makalu-Barun National Park (Fig. 1) was reported that formed a 2-3-km-long, 500-m-wide lake at its confluence with the Arun River (Kathmandu Post, April 21, 2017). Debris had dammed the floodwaters directly above the village of Barun Bazaar, which displaced 10 families from their homes, destroyed fields, and threatened to impact at least 80 families living within the immediate area in the event that the dam suddenly failed (Shakya 2017). The lake also threatened downstream villages that included Phaksinda, Diding, Chetabesi, Lumningtar, and other riverside communities in Bhojpur and Dhankuta districts (MyRepublica 2017), as well as construction activities of the recently approved Upper Arun hydropower project, located $2 \mathrm{~km}$ downstream (Kathmandu Post 2017a, b; USAID 2014).

Government response was swift, deploying a team from the Nepal Army and Nepal Police to assist endangered people and drain the lake if necessary. Fortunately, the lake drained spontaneously on April 21, 2017, less than $24 \mathrm{~h}$ after it formed. Attempts to identify the source of the flood by the Nepal Army were thwarted when bad weather prevented a helicopter reconnaissance of the upper Barun region (MyRepublica 2017). Speculations regarding the cause and source of the flood ranged from heavy rains, to flooded tributaries of the Barun, to a GLOF from the Lower Barun glacial lake (Glacier Hub 2017). Beginning May 23, 2017, we conducted a 2-week field study in the Barun valley to assess the likely cause and source of the flood.

\section{Methods}

The trigger mechanisms and subsequent flood were re-constructed through a combination of (1) remote sensing (helicopter flyover, 


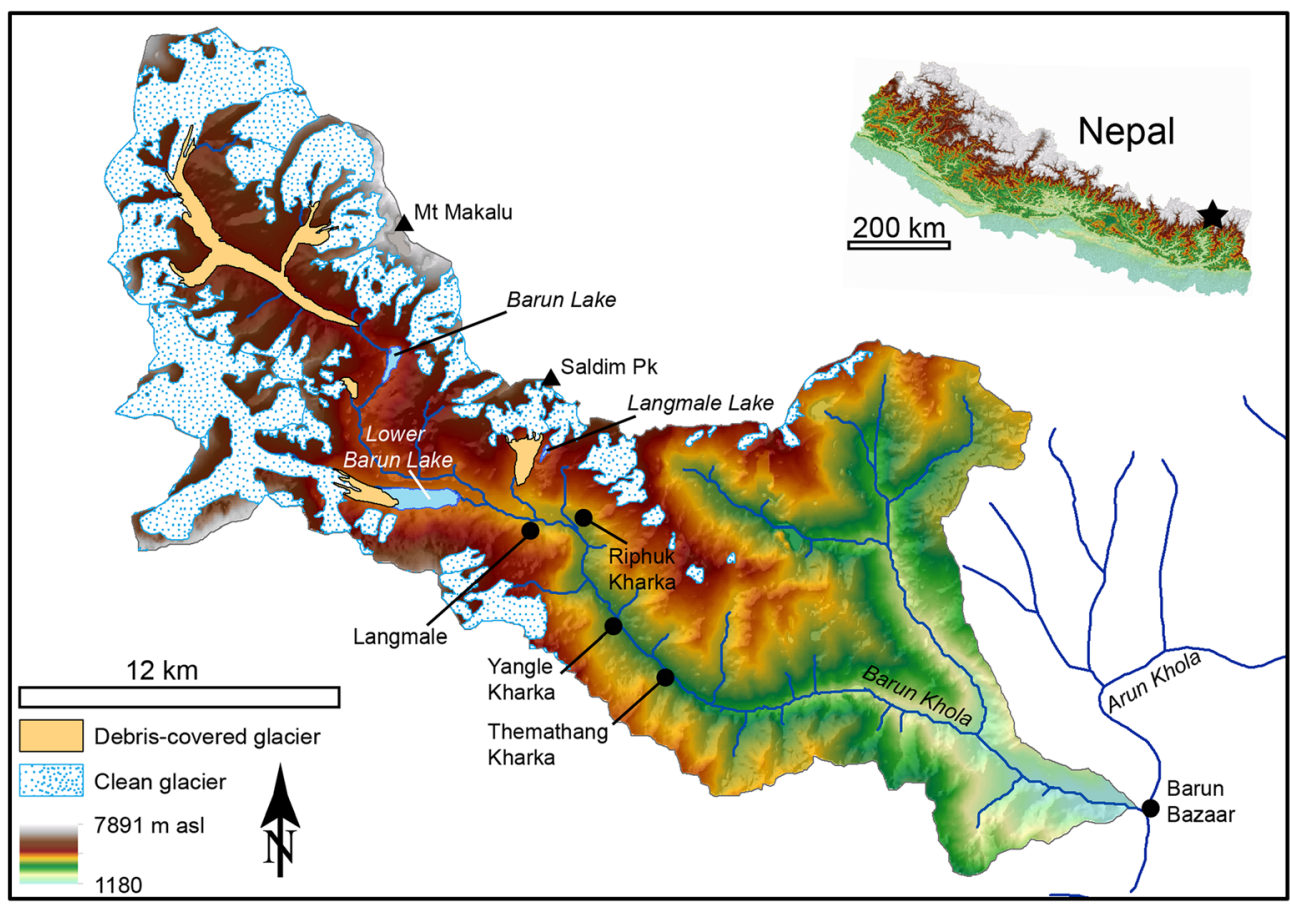

Fig. 1 Barun River catchment in eastern Nepal (star on upper right country inset) showing the location of Langmale, Barun, and Lower Barun glacial lakes, Saldim Peak, and kharka (grazing) areas impacted by the flood

repeat satellite imagery analysis, repeat oblique photography, hazard/risk assessment); (2) field measurements (survey of high water marks and wetted channel cross sections, sampling of airand flood-deposited particle sizes) followed by flood reconstruction using the critical depth method, literature-based velocity estimates, and hydrograph constraints; (3) numerical GLOF modeling; and (4) eyewitness reports and video.

\section{Remote sensing}

A helicopter reconnaissance was used to photograph and video observations of the Barun River and prospective GLOF triggering mechanisms on May 3, 2017, 2 weeks after the main flood event. These observations were supplemented using repeat satellite imagery analysis (source: WorldView-2 (DigitalGlobe, Inc.) and PlanetScope (Planet Team 2016)) to identify flood-related features such as avalanche paths, changes in glacial lake size, and riverbed scouring. Repeat oblique photography of Saldim Peak (6388 m) was used to illustrate the most likely trigger of the GLOF event, i.e., a rockfall from the mountain's northwest face. An assessment of the hazard and flood risk associated with Langmale glacial lake was conducted retroactively to model potential avalanche and rockfall trajectories and the stability of the terminal moraine following the methods of Rounce et al. (2017a). Avalanche- and rockfall-prone areas were identified based on slope and land classification criteria using the $30 \mathrm{~m}$ ASTER GDEM V2 (ASTER GDEM Validation Team 2011), the Randolph Glacier Inventory Version 5.0 (Nuimura et al. 2015; RGI Consortium 2017), and Landsat 7 and 8 images from September 12, 2000 and December 21,2016 , respectively. The potential downstream impacts of a flood from Langmale glacial lake were also modeled using the MC-LCP model (Watson et al. 2015), a geometric flood model, for comparison with a 2-D numerical model (see "Numerical GLOF modeling") and the actual event.

\section{Field measurements and analysis}

Field measurements included surveys of wetted channel cross sections at peak flow (based on high water marks), surveys of wetted cross sections of flow in the Barun River 1 month after the flood, and particle size measurements of airborne and flood deposits. Between May 23 and June 6, 2017, six channel cross sections were selected in relatively straight, uniform reaches of the flood path, where erosional and depositional processes would be minimized. High water marks consisting of new flood deposits were identified at each cross section. The wetted cross section at peak flow was assumed to stretch from the uppermost high water mark on the left bank to the uppermost high water mark on the right bank of the river. Cross sections were surveyed using a Forestry Pro 550 laser rangefinder, tape measure, laser level, and staff gage.

Peak flood discharge and 1 month post-flood stream discharge were estimated using the critical depth method, which has been used successfully to estimate flows in high-gradient streams where Froude numbers approach the value of one (Grant 1997; Jarrett 1984, 2008, 2016; Jarrett and England 2002). The discharge equation is as follows:

$Q=A V_{c}$

where

$Q \quad$ Discharge $\left(\mathrm{m}^{3} \mathrm{~s}^{-1}\right)$ 
Cross-sectional area of flow $\left(\mathrm{m}^{2}\right)$, with depth corrected for cosine of thalweg slope

$V_{c} \quad$ Critical velocity $\left(\mathrm{m} \mathrm{s}^{-1}\right)$

$$
\text { and }
$$

$V_{c}=F \sqrt{D g}$

F Froude number (dimensionless ratio of inertial and gravitational forces on fluid flow)

$D$ Mean depth (m) of flow, corrected for cosine of thalweg slope $g$ Acceleration due to gravity $\left(9.8 \mathrm{~m} \mathrm{~s}^{-2}\right)$

The Froude number associated with the Barun River was assumed to be 1 based on the criteria for critical flow, i.e., competent high gradient stream (slope $>0.01$ ) with streambed particle size ranging from sand to boulders (Grant 1997). The peak flood discharge was characterized as a hyper-concentrated flow, also fitting the criteria for critical flow. It is possible that excessive debris could have created debris flow conditions with supercritical flow $(F>1)$ in some upper reaches, which would result in underestimating flood discharge, although this appears unlikely based on the sampled flood deposits (see "Field measurements and analysis"). Channel slope was high enough (0.06-0.30) that a cosine correction was applied to avoid overestimating the depth of flow.

Peak discharge velocities of historic GLOFs were drawn from previous studies to allow comparison with the peak discharges calculated using the critical depth method. Based on the values of estimated peak discharge, in combination with flood timing estimates from video and oral testimonies, a hydrograph was constructed for the flood above Yangle Kharka. The total flood volume estimated from the hydrograph was further constrained by the low discharge values below Yangle Kharka.

Airborne and flood-deposited sediments were collected for textural analysis at five sites, beginning at the source lakebed and ending in the Yangle Kharka floodplain $7.0 \mathrm{~km}$ downstream. Grain size distribution for these samples was measured using the hydrometer method (U.S. Department of Agriculture (USDA) 2014).

\section{Numerical GLOF modeling}

A simulation of the GLOF was performed using the Basic Simulation Environment for Computation of Environmental Flow and Natural Hazard Simulation (BASEMENT) model, an openaccess numerical model based on the 2-D shallow water equations (Vetsch et al. 2017). BASEMENT's inclusion of sediment transport makes it particularly suitable for GLOF simulations, since it can simulate erosion, scouring, and debris flow in addition to water flow (Worni et al. 2014); moreover, it is a 2$\mathrm{D}$ model, which is superior to the geometric and 1-D models that have been used for this type of application (Bricker et al. 2017). In addition, characteristics of the overtopping wave were validated with the Heller-Hager model, which combines analytical and empirical equations to study wave generation and propagation resulting from mass movement into a reservoir (Heller et al. 2009).
A digital elevation model (DEM) of the area was taken from NASA's High Mountain Asia 8-m DEMs Derived from Cross-track Optical Imagery, version 1 (Shean 2017). Data gaps were filled using the mean of the nearest neighbors in each cardinal direction; the resulting DEM was further hydrologically corrected by filling all sinks to the elevation of lowest neighbor. The DEM was then converted to a triangulated irregular network (TIN) mesh in QGIS (QGIS Development Team 2016) for use in BASEMENT. Finally, a lake depth of $13.29 \mathrm{~m}$ was burned into the TIN mesh to create a lake volume of 1.1 million $\mathrm{m}^{3}$.

The moraine damming Langmale Lake was approximately $75 \mathrm{~m}$ wide, $100 \mathrm{~m}$ long, and $40 \mathrm{~m}$ high (Fig. 2). The moraine lacked vegetation, which is common for contemporary moraine-dammed lakes since they are typically young and located at high elevations (Costa and Schuster 1998). The moraine was assumed to not have an ice-core, since no ice was visible after the incision of the GLOF and no melt ponds or ice cliffs were observed on the moraine prior to the event. The lake's relatively steep moraine and its close proximity to the steep glacier front and surrounding rock-walled cirques only increase its potential hazard. Two cross sections of the moraine-one along the moraine's length and one along its width (Fig. 2)-were analyzed to assess the erosion resulting from the overtopping wave.

The avalanche material's density was interpolated from several sources. Studies on pure rockslides in the region reported densities from $1950 \mathrm{~kg} \mathrm{~m}^{-3}$ (Yigong rock avalanche; Wang et al. 2017) to $2200 \mathrm{~kg} \mathrm{~m}^{-3}$ (Langtang rockslide; Kargel et al. 2016), whereas most ice- and snow-dominated avalanches have densities around $1000 \mathrm{~kg} \mathrm{~m}^{-3}$ (Schneider et al. 2014; SomosValenzuela et al. 2016). A mixed rock (30\%) and ice (50\%) avalanche in Alaska had a density of $1500 \mathrm{~kg} \mathrm{~m}^{-3}$ (Sosio et al. 2012). Based on visual estimates at Langmale, the ratio of rock/ debris to snow/ice was estimated to be $3: 2$, so a density of $1600 \mathrm{~kg} \mathrm{~m}^{-3}$ was assumed.

The mass entry rate of the avalanche into the lake was adapted from Lala et al. (2018), which simulated potential avalanches and resulting impulse wave-induced GLOFs at the nearby Imja Tsho. Because Langmale glacial lake was mostly filled to its previous water level with debris, it was assumed that 1.1 million $\mathrm{m}^{3}$ entered the lake, and the inflow of avalanche mass from Imja Tsho was scaled linearly such that its total volume was equal to this number. BASEMENT only accepts water as inflow; hence, to accurately depict the momentum transfer of the avalanche into the lake, the mass entry rate was further scaled by 1.6 to account for the ratio of avalanche density at Langmale to that of water (1600 $\mathrm{kg} \mathrm{m}^{-3}$ versus $1000 \mathrm{~kg} \mathrm{~m}^{-3}$; Fig. 3). To ensure that this inflow of water was not included in the flood in addition to the initial volume of lake water, no erosion was permitted at the lake bed, which allowed the lake to retain most of its initial volume and only release $\sim 1.3$ million $\mathrm{m}^{3}$.

A previous study of moraines in the Nepal Himalaya found that gravel and coarser boulders comprised $80-90 \%$ of the particle size distribution (Hambrey et al. 2008), which suggests that the finer sediments that were sampled in the field (Table 1) are not representative of the terminal moraine. Therefore, we used two grain size distributions from Worni et al. (2013) (Table 2), which were used to model GLOFs using BASEMENT in the Indian Himalaya. The use of two distributions also provided some quantification of uncertainty associated with the 


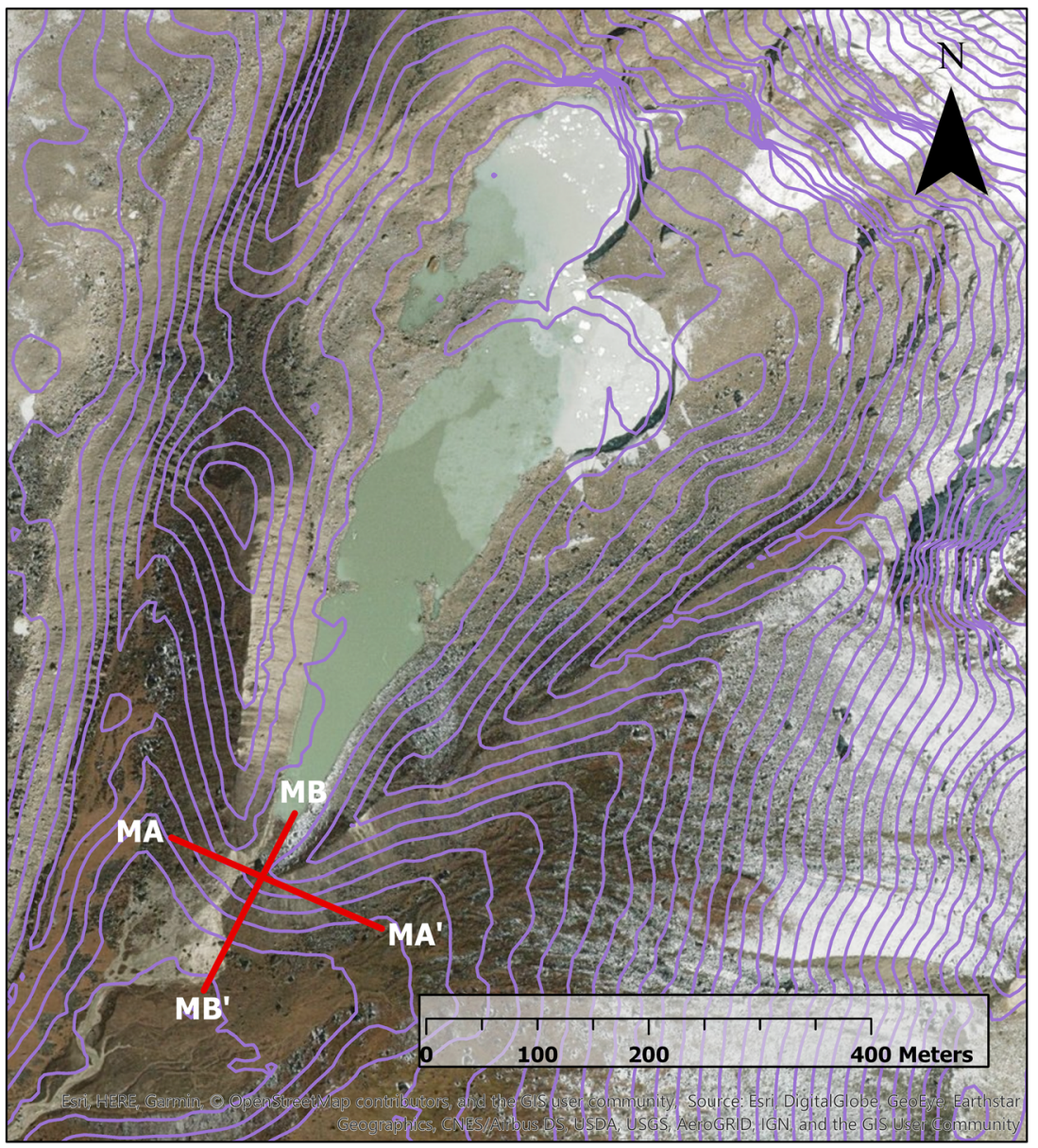

Fig. 2 Contour map of Langmale lake showing the geometry of the moraine and cross sections used to analyze erosion. Contour intervals are $10 \mathrm{~m}$.

erosion due to the grain size distributions. Density and porosity were determined from a sample taken at Imja Tsho (Lala et al. 2018), yielding values of $1800 \mathrm{~kg} \mathrm{~m}^{-3}$ and $30 \%$, respectively.

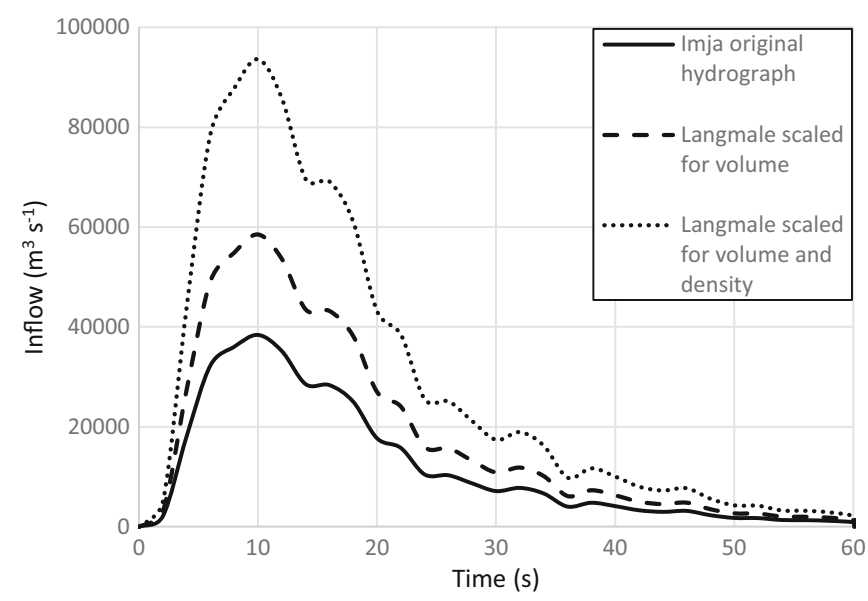

Fig. 3 Inflow hydrographs for BASEMENT simulation, showing the original hydrograph taken from Imja Tsho (Lala et al. 2018), and its adaptation for the Langmale GLOF model

\section{Eyewitness reports and video}

Informal, non-structured interviews (Sheftel and Zembrzycki 2013) were conducted with flood eyewitnesses, lodge owners, climbing guides, seasonal Makalu basecamp workers, and one other western scientist who visited the Barun valley on May 6, 2017 with a student group (Carpenter 2017). The oral testimony component provided valuable information regarding the timing of the Saldim Peak rockfall, resultant avalanche, flood, color and content of peak flood water, geomorphic and infrastructure damage, fatalities, and other attributes of the event that were followed up with further field investigations. Eyewitness video provided real-time footage of the flood in the vicinity of Yangle Kharka while facilitating the calculation of peak discharge and flood volume totals.

\section{Results}

\section{Remote sensing}

The helicopter reconnaissance on May 2, 2017 revealed that Lower Barun ( $\left.27^{\circ} 49^{\prime} 49^{\prime \prime} \mathrm{N}, 87^{\circ} 05^{\prime} 43^{\prime \prime} \mathrm{E} ; 4552 \mathrm{~m}\right)$ and Barun $\left(27^{\circ} 50^{\prime} 42^{\prime \prime} \mathrm{N}\right.$, $87^{\circ} 05^{\prime}$ 01.4" E; $4843 \mathrm{~m}$ ) glacial lakes were intact, while Langmale glacial lake $\left(27^{\circ} 48^{\prime} 47^{\prime} \mathrm{N}, 87^{\circ} 08^{\prime} 21^{\prime \prime} \mathrm{E} ; 4843 \mathrm{~m}\right)$ appeared to have recently drained (https://www.youtube.com / watch? $=\mathrm{kMOS}_{7} \mathrm{Yt}_{45} \mathrm{jY} \&$ feature=youtube). Satellite imagery (WorldView-2 and PlanetScope) revealed that between February 19, 2017 and May 8, 2017, the lake area was reduced from 0.083 to 


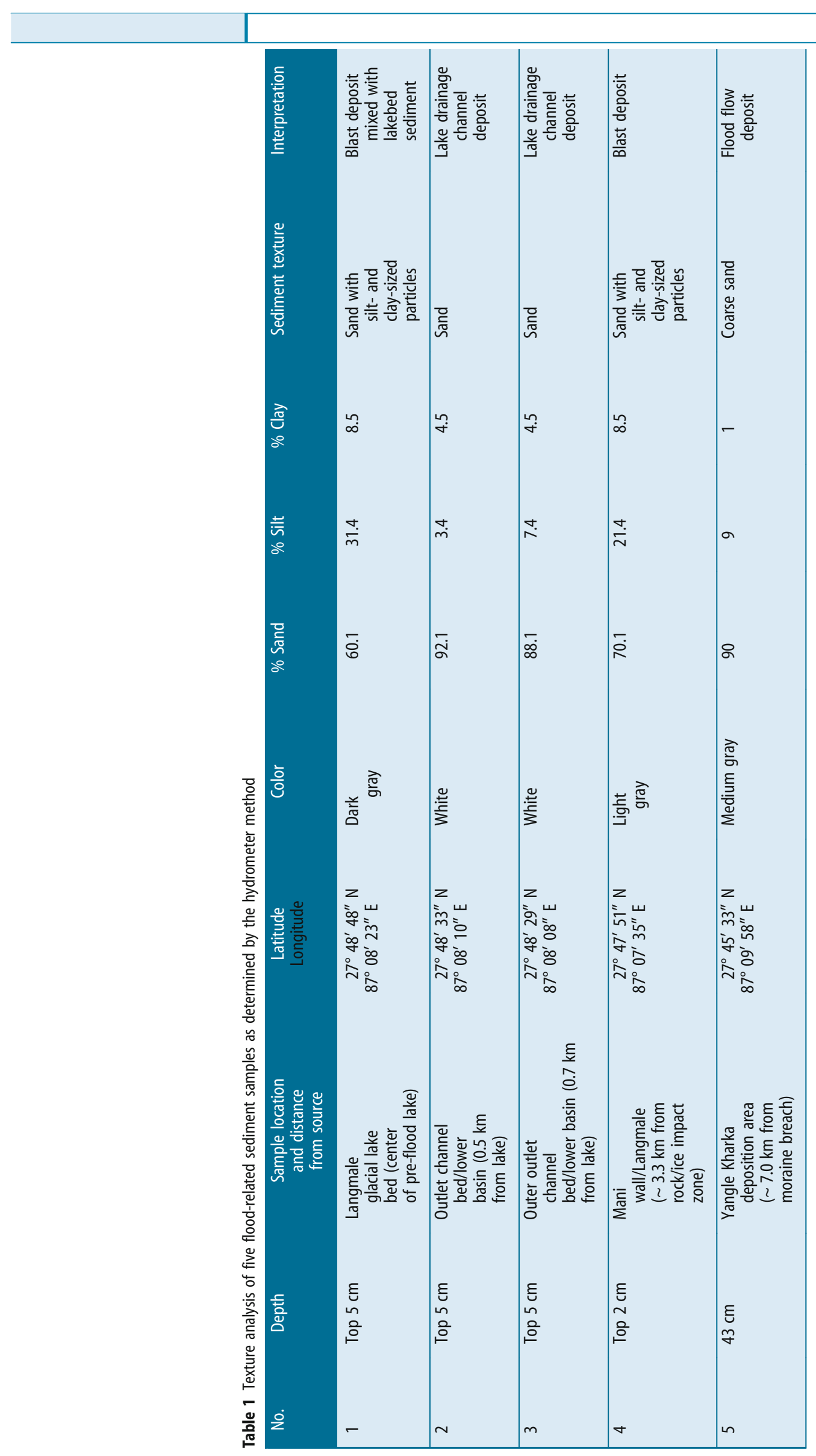


Table 2 Grain size distributions from Worni et al. (2013) used to assess the uncertainty associated with the moraine erosion due to the inclusion of larger grain sizes

\begin{tabular}{llll} 
& $\begin{array}{c}\text { Worni et al. } \\
\text { (2013) A }\end{array}$ & \multicolumn{2}{c}{$\begin{array}{c}\text { Worni et al. } \\
(2013)\end{array}$} \\
Size $(\mathrm{mm})$ & Fraction (\%) & Size $(\mathrm{mm})$ & Fraction (\%) \\
\hline 4 & 28 & 4 & 22 \\
\hline 8 & 12 & 11 & 10 \\
\hline 22 & 16 & 32 & 21 \\
\hline 64 & 14 & 90 & 22 \\
\hline 128 & 20 & 256 & 15 \\
\hline 180 & 10 & 720 & 10 \\
\hline
\end{tabular}

$0.036 \mathrm{~km}^{2}$ (Supplementary material: Fig. S1), which indicates that at least part of the flood's source was from the drainage of Langmale glacial lake (Fig. 4 (B)). Based on empirical volume-area equations for glacial lakes (Cook and Quincy 2015), the lake volume was estimated to have decreased from 1.1 million $\mathrm{m}^{3}$ on February 19, 2017 to 0.3 million $\mathrm{m}^{3}$ on May 8, 2017. Footage from the helicopter showed the terminal moraine was clearly breached and zones below the lake were scoured. Large areas of the flat pastures at Yangle Kharka were also destroyed by the scouring and deposition of the flood (Fig. 4 (C, D)). A short flight down the Barun River valley revealed that the flood became more channelized beyond Yangle Kharka, scouring the river bed to bedrock.

Repeat oblique photography of the northwest face of Saldim Peak $(6388 \mathrm{~m})$ revealed the primary flood trigger, i.e., a large rockfall from the mountain's northwest face (Fig. 5). Langmale glacial lake was previously excluded from the hazard assessment conducted by Rounce et al. (2017a), since it was below the area threshold used in that study. However, the mass movement trajectories as calculated by the methods described in Rounce et al. (2017a) showed that Langmale glacial lake was susceptible to both avalanches and rockfalls entering the lake, which included a rockfall with a volume of $0.3 \times 10^{6} \mathrm{~m}^{3}$ from Saldim Peak. The terminal moraine did not appear to be ice-cored, but the steep lakefront area angle (Fujita et al. 2012), an indicator of the steepness of the moraine, of $16^{\circ}$ indicated that the lake was susceptible to selfdestructive failure. The combination of potential mass movement entering the lake and self-destructive failure classified this lake as very high hazard with a potential flood volume of $1.1 \times 10^{6} \mathrm{~m}^{3}$. The extent of a potential GLOF was modeled using the MC-LCP model (Watson et al. 2015) and revealed that 33 buildings, 4 bridges, and $0.76 \mathrm{~km}^{2}$ of agricultural land could be impacted, which included the 4 buildings in Yangle Kharka that were impacted by the actual event. These downstream impacts were classified as high. The combination of the hazard and the downstream impacts retroactively suggest that Langmale glacial lake was a very high risk for a GLOF.

\section{Field measurements and analysis}

Peak flood discharge was estimated at six locations along the Barun River (Fig. 6). Cross sections were chosen in relatively straight, stable reaches to avoid areas of significant erosion, deposition, or superelevation around bends. Measurement of multiple cross sections helped to address the large uncertainty that is inherent in reconstructing a flood with massive depositional and erosional impacts, possible temporary debris-flow characteristics, a non-uniform channel, and potential fluctuations between supercritical and subcritical flow. For example, the relatively lower estimated peak discharges at $2.4 \mathrm{~km}$ and $3.6 \mathrm{~km}$ below the source reflect reaches that respectively shallowed in slope as the flood reached the valley bottom and spread across an expanded floodplain in the partly wooded pastures of Nhe Kharka. Both sites likely experienced net deposition, resulting in underestimates of peak discharge. The relatively higher discharge at $4.9 \mathrm{~km}$ below the source reflects a narrowing straight reach with good bedrock control on the right and left banks and possible erosion within the channel bed, which could result in overestimating peak discharge. From the helicopter footage, significant superelevation around major bends in the flood path is clearly visible. These bends were avoided in selecting cross-section locations, but even at its most uniform the flood path was not a straight channel, and the difference of several meters in the height of high water marks between the left and right banks is notable. In addition to superelevation around smaller bends, it is possible that sloshing of the flood from side to side may have contributed to the difference in height of high water marks.

Flood channel cross sections were erratic near the source of the flood and became more uniform as the flood moved downstream (Fig. 6). A number of large remnant boulders upstream from Yangle Kharka, most likely deposited during a previous flood event (Chaudhary 2013; Byers et al. 2014; Carpenter 2017), appeared to be undisturbed by this event, i.e., they were still capped with moss, shrubs, and approximately 40-year-old fir trees. Bedload otherwise became smaller and more uniform in the vicinity of Yangle Kharka.

The peak velocities of historic GLOFs in nearby drainages provide some insight to the range of potentially expected values for the Langmale flood. Vuichard and Zimmermann (1987) report peak velocities of $4-5 \mathrm{~ms}^{-1}$ for the 1985 Dig Tsho flood. Dwivedi et al. (2000) report a range of $5-10 \mathrm{~ms}^{-1}$ for the 1998 flood from Tam Pokhari. A range of $4-8 \mathrm{~ms}^{-1}$ seems reasonable to use for comparison with the critical depth estimates. Peak discharge based on these velocities ranged from 1890 to $8651 \mathrm{~m}^{3} \mathrm{~s}^{-1}$ (Table 3). For reference, the velocity at normal monsoon flow in the Barun River at Yangle Kharka was measured at $3.1 \mathrm{~ms}^{-1}$ on August 13, 2014, corresponding to a discharge of $35 \mathrm{~m}^{3} \mathrm{~s}^{-1}$ (Byers et al. 2014). Premonsoon discharge in the Barun River was measured 1 month after the flood as follows: May 28, $7.9 \mathrm{~m}^{3} \mathrm{~s}^{-1}$ at the Nhe bridge; May 29, $7.7 \mathrm{~m}^{3} \mathrm{~s}^{-1}$ above Yangle Kharka; and June 2, $6.7 \mathrm{~m}^{3} \mathrm{~s}^{-1}$ below Yangle Kharka.

Peak discharge estimates from the critical depth method range from 2593 to $7640 \mathrm{~m}^{3} \mathrm{~s}^{-1}$ (Table 3), which fall within the estimates based on plausible peak velocities for the event. We estimate peak discharge for the event as $4400 \pm 1800 \mathrm{~m}^{3} \mathrm{~s}^{-1}$. At Yangle Kharka, the flood water spread out over the relatively flat and wide grazed floodplain ( $300 \mathrm{~m}$ wide $\times 800 \mathrm{~m}$ long, $3.5 \%$ slope) and was gradually released through the bedrock constriction at the lower end of the Yangle Kharka basin (Fig. 6 (map) and profile (G)). The peak discharge below this bedrock constriction is estimated in a stable bedrock reach as $800 \pm 250 \mathrm{~m}^{3} \mathrm{~s}^{-1}$.

The total flood volume is constrained by the maximum flood height of $4.8 \mathrm{~m}$ in the broad floodplain at Yangle Kharka, considered together with the reduced discharge below the bedrock 

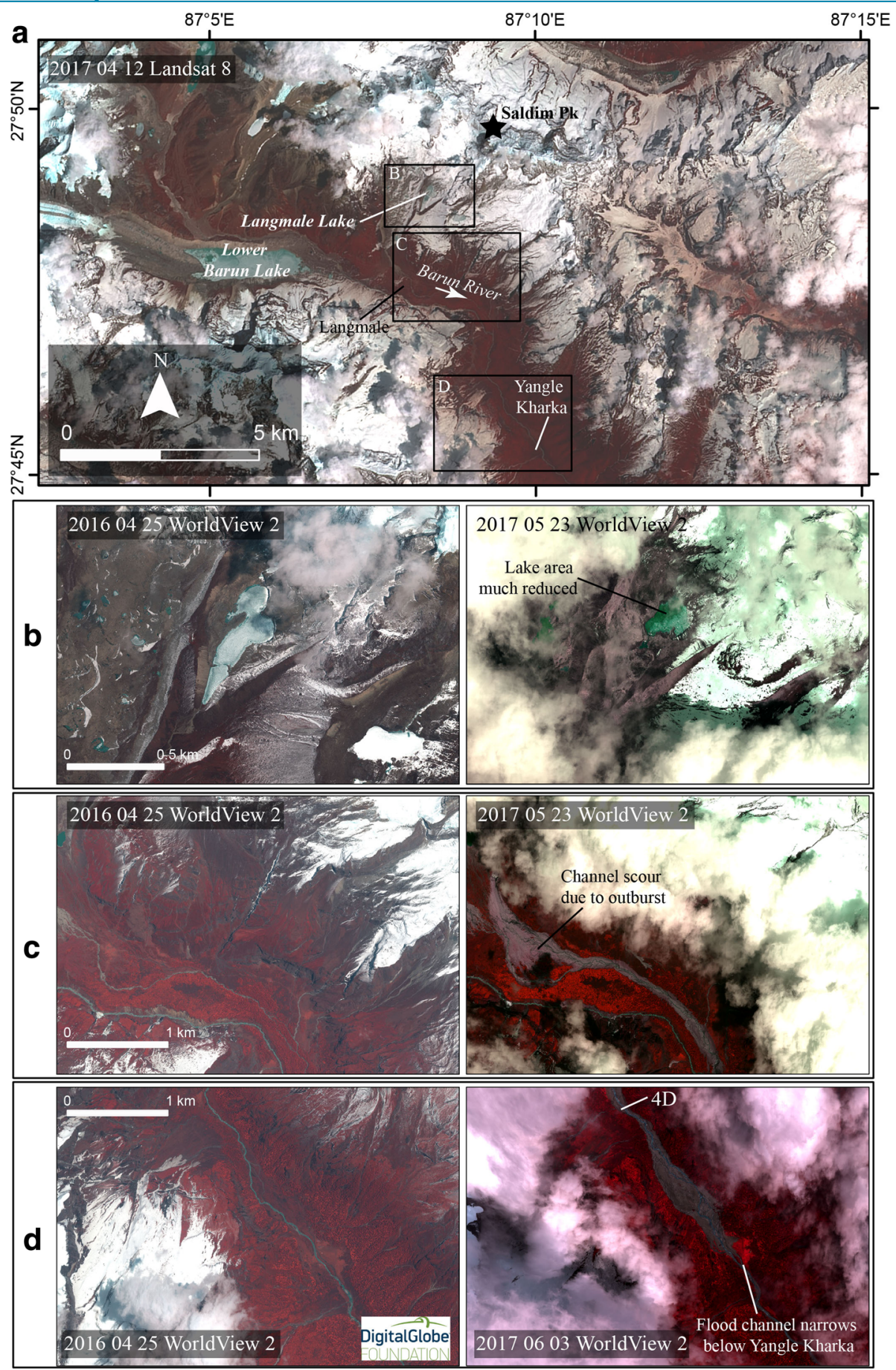

Fig. 4 Satellite imagery of the study area. (A) A Landsat 8 scene of the upper Barun River valley. Boxes show extents of (B), (C), and (D), which are high-resolution (2 m, WorldView-2) multispectral before and after views of key sites along the river. (B) A before and after pair showing the reduction in area of Langmale glacial lake. (C) The channel scour and deposition along the Barun River created by the outburst flood. (D) The flood impacts in the broad floodplain area of Yangle Kharka, followed by the abrupt narrowing of the flood channel below the bedrock constriction at the lower end of Yangle Kharka. Inset (D) shows the location of boulders (4D) deposited near Nhe Khaka (Fig. 12d) (imagery courtesy of the DigitalGlobe Foundation)

constriction exiting Yangle Kharka, and the knowledge that a lake did not form in Yangle Kharka. In other words, the flood was small enough that it could drain quickly, even with a peak outflow from Yangle Kharka that was much less than the peak inflow. Given the flow measurements and the potential volume of water that could be stored in Yangle Kharka, we estimate a total flood volume of no more than $1.3 \times 10^{6} \mathrm{~m}^{3}$. The minimum total flood volume is constrained by the estimated peak flow measurements and the shape of the hydrograph, i.e., the duration of the rising limb, peak flow, and falling limb of the event. 


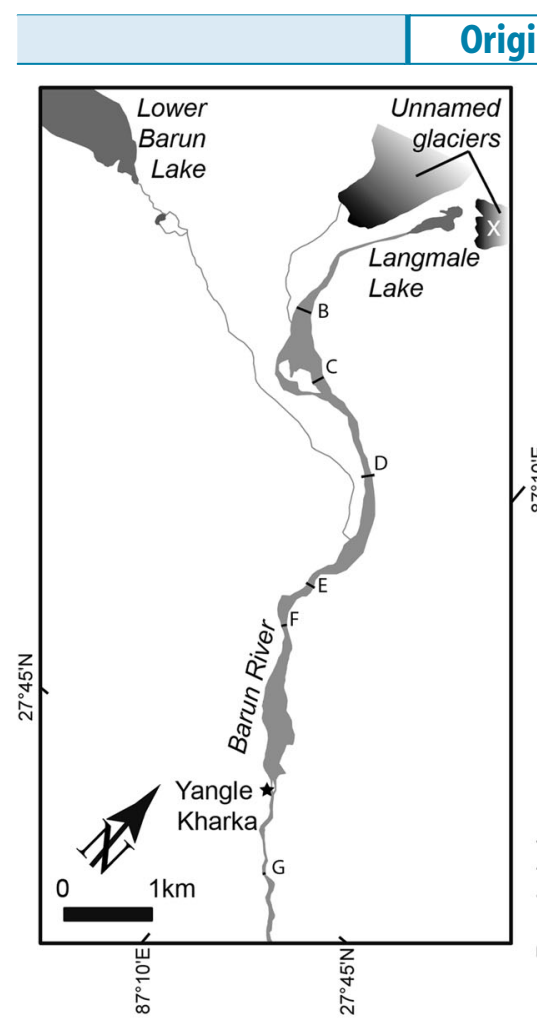

Original Paper
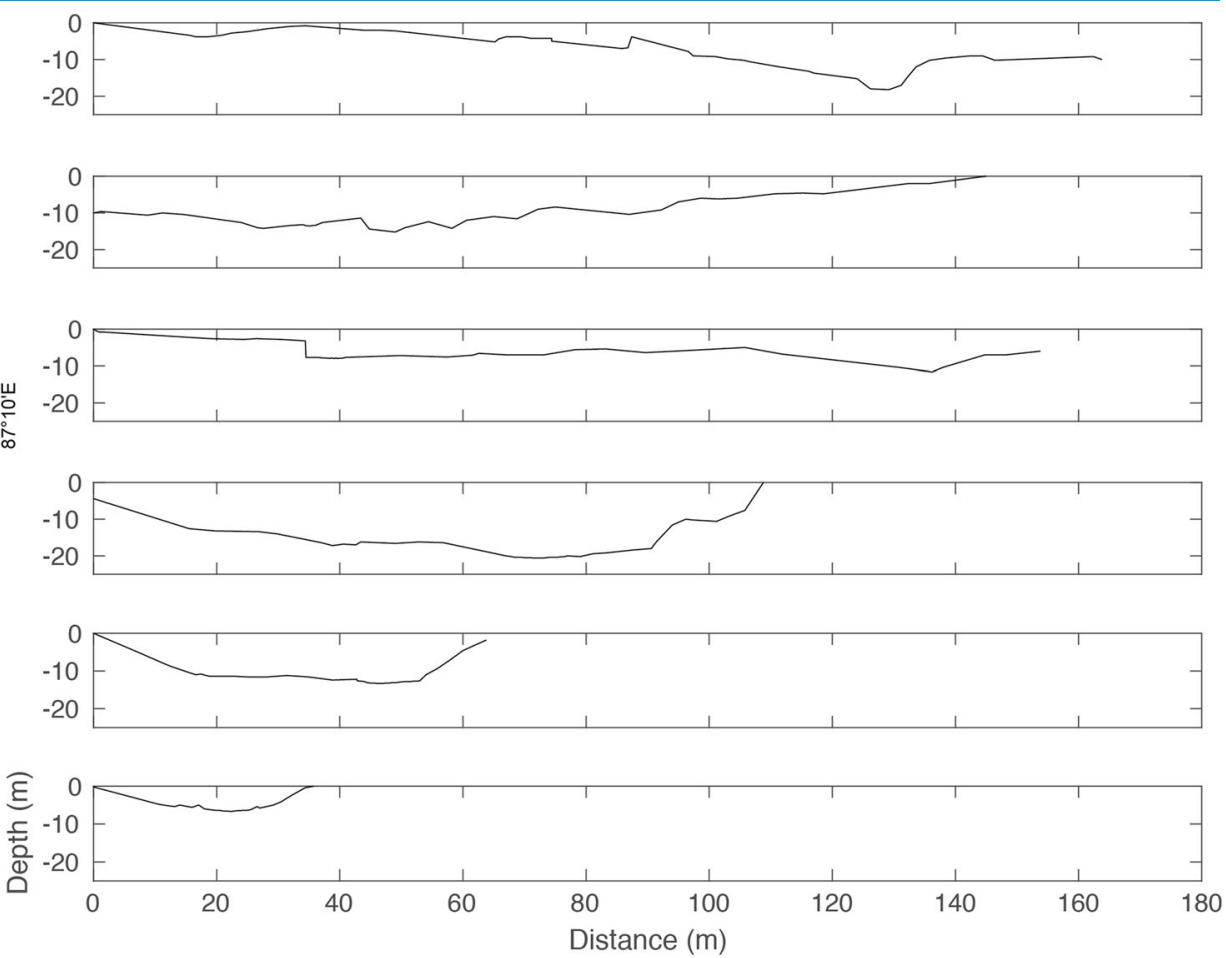

Fig. 6 Cross sections on the Barun River during peak flow based on high water marks between the banks of the river, which show the transition from highly non-uniform wetted channels near the source of the flood to more uniform channels further downstream. Map to the left shows location of the glacier that collapsed above Langmale glacial lake ("X"), cross-section sites, and width of scouring and deposition in the Barun River channel

With the assistance of flood eye witness Dorje Sherpa, we measured the recollected height of the water over time within the Yangle floodplain where structures provided reference points, and on a large boulder on the right bank of the Barun River at Yangle Kharka. Combining oral accounts with examination of the flood videos, we were able to reconstruct the approximate shape of the

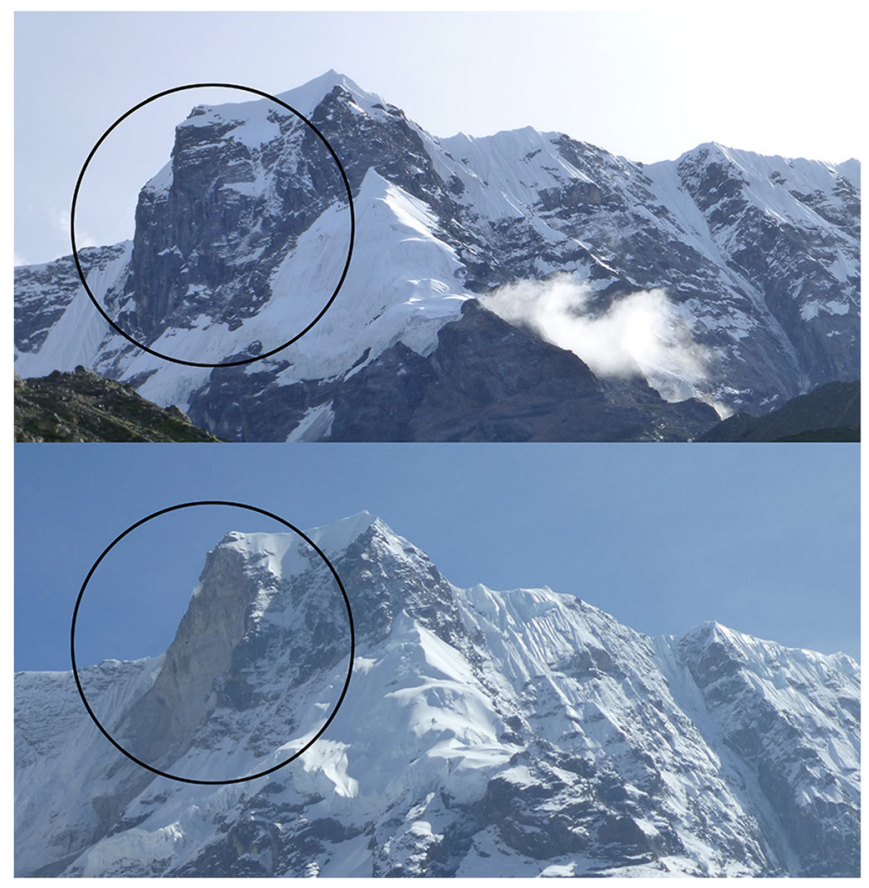

Fig. 5 Before (top) and after (bottom) photographs of the large rock face that collapsed on April 20, 2017 (top photograph: E. Byers, 2016; bottom photograph: A. Byers 2017) 
Table 3 Cross-section data and peak discharge estimates based on critical depth method (CD) and literature-based peak velocity $\left(v_{\mathrm{p}}\right)$ estimates of 4 , 6 , and 8 ms ${ }^{-1}$

\begin{tabular}{|c|c|c|c|c|c|c|c|c|}
\hline $\begin{array}{l}\text { Cross } \\
\text { section }\end{array}$ & $\begin{array}{l}\text { Distance } \\
\text { from source } \\
(\mathrm{km})\end{array}$ & Slope & $\begin{array}{l}\text { Wetted } \\
x-s \text { area } \\
\left(\mathrm{m}^{2}\right)\end{array}$ & $\begin{array}{l}\text { Mean } \\
\text { depth } \\
(\mathrm{m})\end{array}$ & $C D$ & $\begin{array}{l}\text { Peak discl } \\
v_{\mathrm{p}}=4 \mathrm{~ms}^{-1}\end{array}$ & $\begin{array}{l}\left.\mathrm{m}^{3} \mathrm{~s}^{-1}\right) \text { estimates } \\
v_{\mathrm{p}}=6 \mathrm{~ms}^{-1}\end{array}$ & $v_{\mathrm{p}}=8 \mathrm{~ms}^{-1}$ \\
\hline $\begin{array}{l}\text { B. } \\
\text { Langm- } \\
\text { ale }\end{array}$ & 1.5 & 0.302 & 740 & 6.42 & 5722 & 2962 & 5183 & 7404 \\
\hline $\begin{array}{l}\text { C. above } \\
\text { Riphuk }\end{array}$ & 2.4 & 0.159 & 565 & 3.90 & 3511 & 2260 & 3955 & 5650 \\
\hline $\begin{array}{l}\text { D. below } \\
\text { Riphuk }\end{array}$ & 3.6 & 0.149 & 472 & 3.07 & 2593 & 1890 & 3307 & 4725 \\
\hline $\begin{array}{l}\text { E. Nhe } \\
\text { bridge }\end{array}$ & 4.9 & 0.129 & 865 & 7.95 & 7640 & 3460 & 6056 & 8651 \\
\hline $\begin{array}{l}\text { F. above } \\
\text { Yangle }\end{array}$ & 5.2 & 0.087 & 592 & 8.49 & 5407 & 2369 & 3554 & 4739 \\
\hline $\begin{array}{c}\text { Average } \\
\text { B-F }\end{array}$ & & & 647 & 5.97 & 4975 & 2588 & 4411 & 6234 \\
\hline $\begin{array}{c}\text { StdDev } \\
\text { B-F }\end{array}$ & & & 155 & 2.41 & 1979 & 621 & 1169 & 1737 \\
\hline $\begin{array}{l}\text { G. below } \\
\text { Yangle }\end{array}$ & 8.3 & 0.062 & 138 & 3.85 & 849 & 552 & 828 & 1104 \\
\hline
\end{tabular}

flood hydrograph at Yangle Kharka using upper and lower peak velocity estimates of $4 \mathrm{~ms}^{-1}$ (peak discharge of $2369 \mathrm{~m}^{3} \mathrm{~s}^{-1}$ ) and $8 \mathrm{~ms}^{-1}$ (peak discharge of $4739 \mathrm{~m}^{3} \mathrm{~s}^{-1}$ ) (Fig. 7). The volume under the hydrograph is set equal to the estimated maximum total flood volume of $1.3 \times 10^{6} \mathrm{~m}^{3}$ of water. Experimenting with smaller flood volumes, we were not able to reproduce a hydrograph with the reported shape, i.e., at smaller flood volumes the peak becomes almost instantaneous rather than the reported sequence of events with the peak spreading out over $10-15 \mathrm{~min}$, much of the flood subsiding by $30 \mathrm{~min}$ and the stream essentially back to normal flow after $1 \mathrm{~h}$. Therefore, we propose that the estimated maximum flood volume is the best estimate of total volume for this event. The estimated total flood volume of $1.3 \times 10^{6} \mathrm{~m}^{3}$ is larger than, but of the same order of magnitude, as the estimated $7.6 \times 10^{5} \mathrm{~m}^{3}$ of water that was drained from Langmale glacial lake, suggesting that floodwater composition was a combination of lake water, snow and ice meltwater from the unseasonably warm weather as described by informants, water released from englacial conduits (Benn et al. 2012; Rounce et al. 2017b), water generated by friction created during the rockfall/ice avalanche, and material (trees, boulders, sediment) scoured by the flood as it advanced downstream. The Langmale flood volume estimate is about a quarter the size of the $5 \times 10^{6} \mathrm{~m}^{3}$ estimated for the well-known Langmoche (Dig Tsho) GLOF of 1985 in the Khumbu region (Vuichard and Zimmermann 1987), which destroyed a nearly completed hydropower station, all bridges for $80 \mathrm{~km}$ downstream, and killed at least five people. The Barun valley is much less populated and developed than the Bhote Kosi valley in the Khumbu, which partly accounts for the lack of fatalities and comparatively minor structural damage experienced as a result of the 2017 Langmale flood.

Texture analysis of freshly deposited sediment supplemented the reconstruction of the sequence of events by characterizing the differences between airborne and flood deposits (Table 1). The covering of whitish sand intermixed with silt- and clay-sized particles upon all surfaces within a $4-\mathrm{km}$ radius of Langmale glacial lake (Table 1 , samples 1 and 4 ) indicates that the initial impact of the Saldim Peak rockfall created a massive dust cloud, a phenomenon similar to that reported by Kargel et al. (2013) and Kargel (2014) for the Seti Kosi flood in 2012 and by Kargel et al. (2015) for the Langtang avalanche following the 2015 Gorkha earthquake. In contrast, flood channel and flow deposits consisted of coarser textures that ranged from sand to coarse sand.

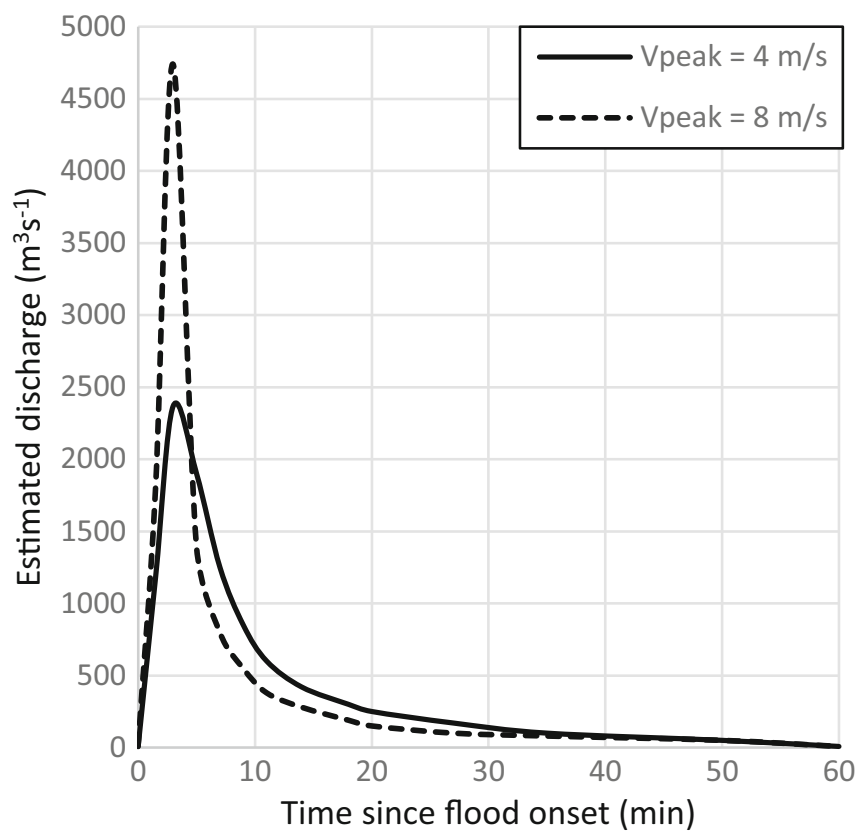

Fig. 7 Estimated flood hydrograph at Yangle Kharka based on the time since the start of the flood. Total flood volume shown is $1.3 \times 10^{6} \mathrm{~m}^{3}$ for upper and lower estimated peak velocities of $4 \mathrm{~ms}^{-1}$ and $8 \mathrm{~ms}^{-1}$ 

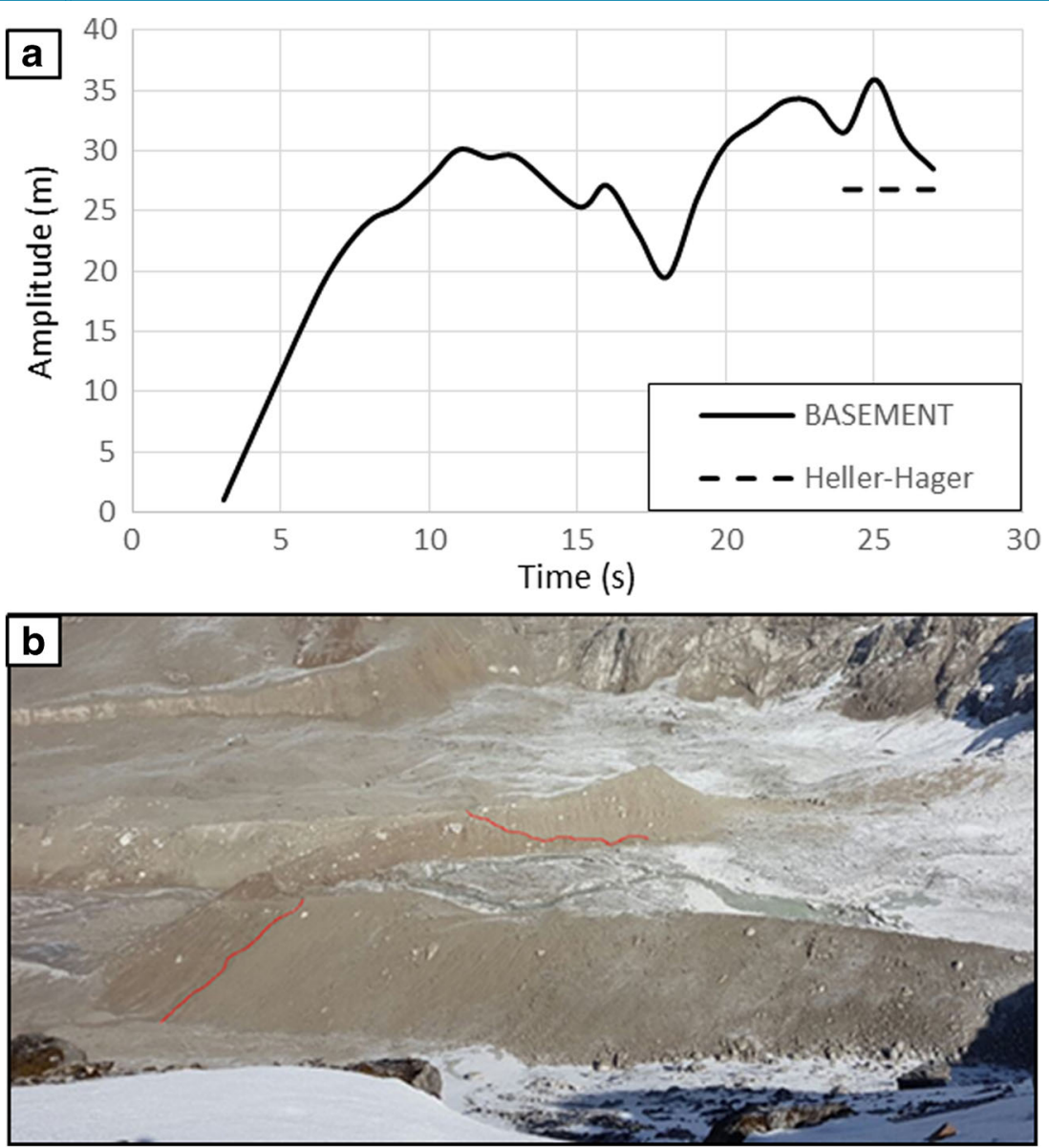

Fig. 8 a GLOF modeling results showing the wave amplitude as it traverses the lake from the BASEMENT simulation and the corresponding Heller-Hager amplitude at the point of overtopping and $\mathbf{b}$ field observations of the path of the surge wave (red lines) that overtopped the left lateral and terminal moraines of Langmale glacial lake (photograph by D. Sherpa)

\section{Numerical GLOF modeling}

BASEMENT was used to model the mass movement entering the lake, the propagation of the tsunami-like wave across Langmale glacial lake, and the ensuing erosion, scouring, and flow of the GLOF. The wave height at the point of overtopping for both BASEMENT and the Heller-Hager (see Supplementary material: Table S1) model agreed, indicating an amplitude of $27.0 \mathrm{~m}$ for the former and $26.8 \mathrm{~m}$ for the latter (Fig. 8a). This agrees with observed evidence of the wave, which left a mark on the moraine indicating a height of at least $25 \mathrm{~m}$ (Fig. 8b).

The overtopping wave caused significant erosion of the terminal moraine, which was most severe along the lake's main outlet channel (Fig. 9). The maximum erosion lowered the outlet channel by approximately 22-25 $\mathrm{m}$ depending on the grain size distribution. This amount of erosion agreed well with field observations (Figs. $8 \mathrm{~b}$ and $12 \mathrm{e}$ ) and confirmed that the GLOF was triggered by the overtopping wave causing a failure of the terminal moraine.

Peak discharge from BASEMENT, $5985 \mathrm{~m}^{3} \mathrm{~s}^{-1}, 3456 \mathrm{~m}^{3} \mathrm{~s}^{-1}$, and $2152 \mathrm{~m}^{3} \mathrm{~s}^{-1}$ for cross sections $\mathrm{B}, \mathrm{C}$, and D, respectively (Fig. 10), also agreed with observed estimates (Table 3). Due to the limited spatial extent of the DEM used for the GLOF model, cross sections E, F, and G were not analyzed. Despite these differences of up to $3 \mathrm{~m}$ in erosion at the moraine, the peak discharge at the downstream channel cross sections did not vary greatly, and both were within the estimated values shown in Table 3.

Inundation depth from BASEMENT (Fig. 11) also agreed with observed scouring (Fig. 4 (C)), although the resolution of the DEM may have contributed to excess spillover onto the western glacier, rather than confining more of the flood to the main eastern channel. This spillover likely accounts for the lower, delayed peak discharge at cross section D (Fig. 10) due to the water rejoining the main channel.

\section{Eyewitness reports and video}

Oral testimony from a climbing guide (Dendi Sherpa, pers. comm. 2017) and lodge owners at the settlement of Langmale (Tashi Sherpa, pers. comm. 2017) confirmed that the flood trigger was a massive rockfall that fell from the southwest face of Saldim Peak $(6388 \mathrm{~m})$ (Fig. 5) the day of the outburst flood. The rockfall was not actually witnessed by anyone, partly because of the heavy fog that covered Saldim Peak that day and also because most of the valley's seasonal residents were up at the Makalu basecamp closing down the season. However, all associated sounds (i.e., avalanche, wind, flood) were heard and/or felt by numerous informants, and the fresh scar left behind on the rock wall was clearly visible from the village (Fig. 5). By comparing and integrating field and laboratory 

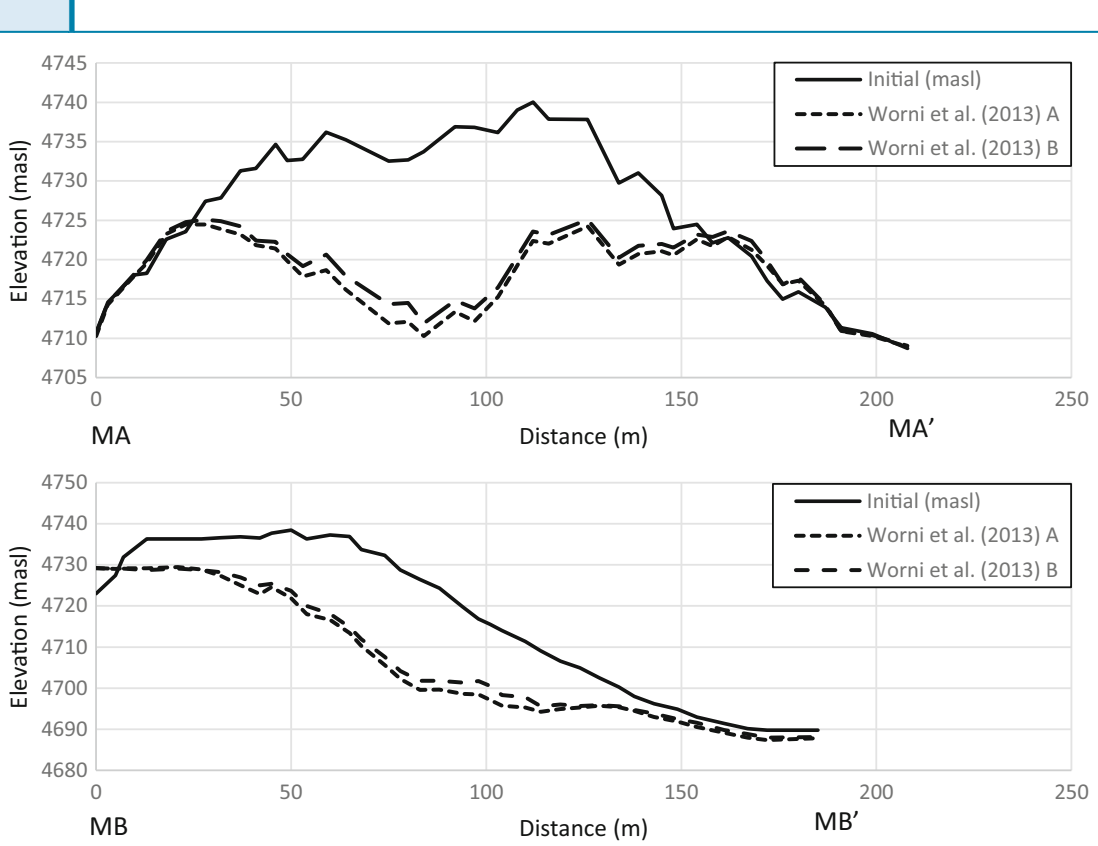

Fig. 9 Cross sections (see Fig. 2) along the width (MA-MA') and length (MB-MB') of the terminal moraine before and after the flood showing the erosion caused by the overtopping wave for two grain size distributions

results with these and other first-hand accounts, a reasonable scenario of the most likely series of events which led to the Langmale GLOF was reconstructed.
The first slope failure occurred around 12:30 p.m. and was relatively small, causing only a minor rise in Barun River's water level when it reached Yangle Kharka. This event was largely
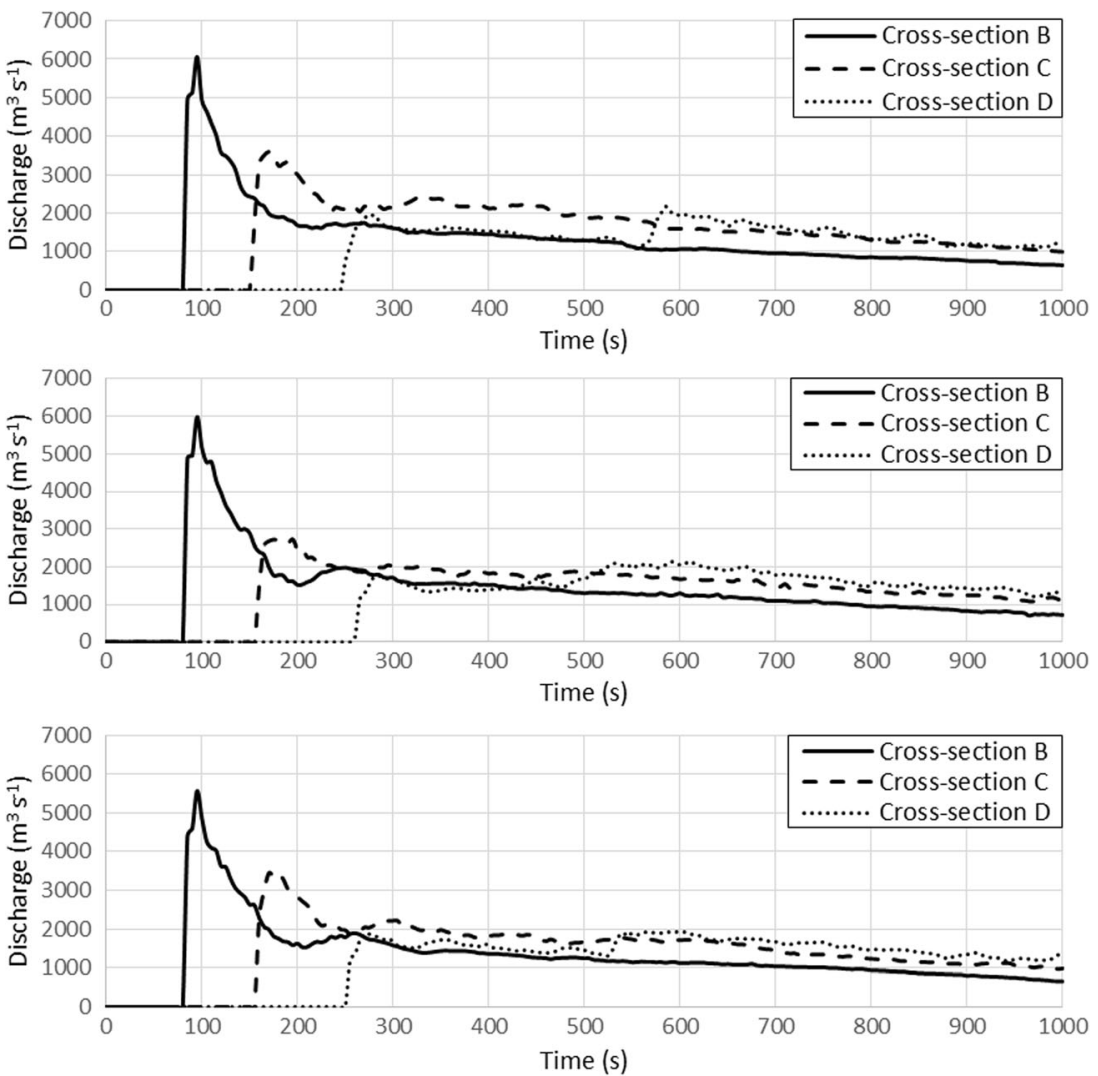

Fig. 10 GLOF modeling results showing discharge at cross sections B, C, and D (see Fig. 6) for grain size distributions from Worni et al. (2013) A (top) and Worni et al. (2013) B (bottom) 


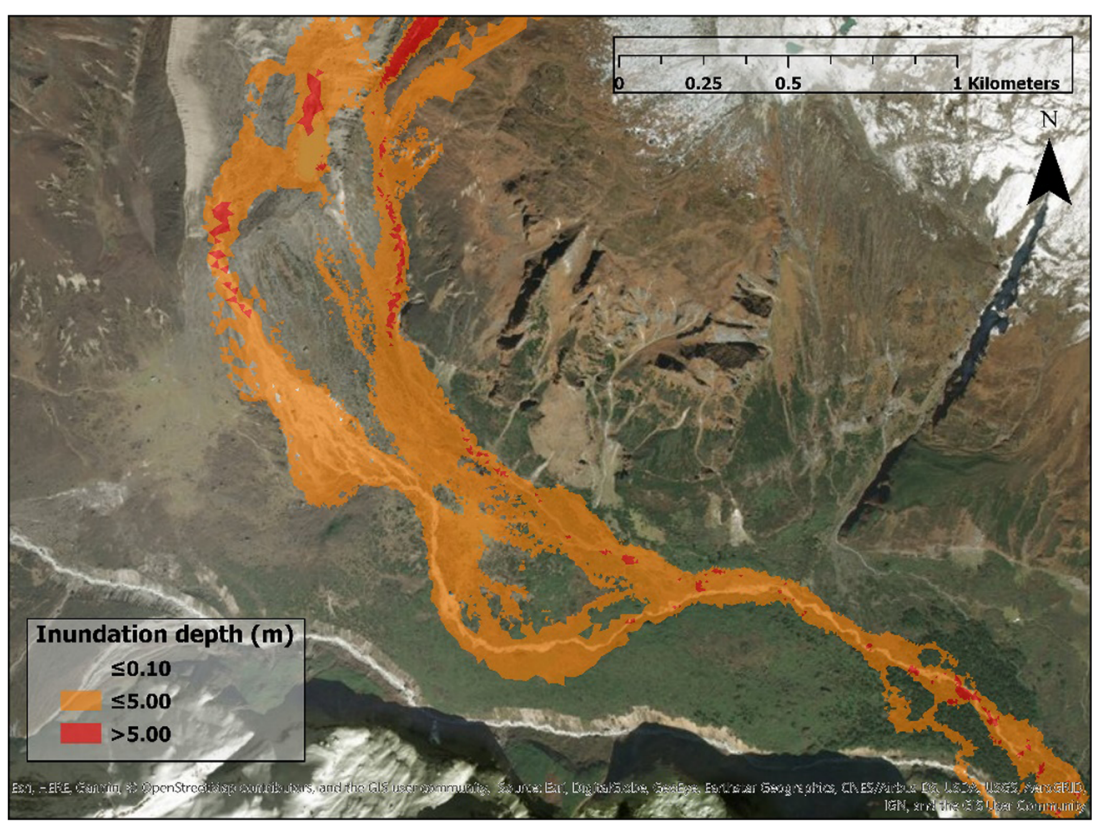

Fig. 11 Maximum inundation depth downstream of Langmale glacial lake from BASEMENT simulation

ignored by villagers and tourist groups alike in the downstream village of Yangle Kharka (Dorje Sherpa, pers. comm. 2017). The second slope failure at 1:30 p.m., however, consisted of a very large volume of rock that fell approximately $570 \mathrm{~m}$ down to the unnamed glacier above Langmale glacial lake ("X" on Fig. 6). The impact precipitated an avalanche, carrying blocks of rock and ice up to $5 \mathrm{~m}$ in diameter (Fig. 12a, b) down another $630 \mathrm{~m}$ into Langmale glacial lake, triggering the GLOF. The rockfall and avalanche also created hurricane-force winds and a huge dust and debris cloud of whitish sand-rich deposits that settled over shrubs, boulders, lodges, mani walls, and all other surfaces in a fan-like pattern from the impact zone to about $4 \mathrm{~km}$ south of Langmale glacial lake (Table 1, sample 4; Fig. 12c). The rockfall left behind a debris fan on top of the glacier, which traced the rockfall's trajectory as it descended to the lake (Supplementary material: Fig. $\mathrm{S}_{1}$ ).

The mass movement that entered Langmale glacial lake caused a tsunami-like wave, between $25 \mathrm{~m}$ and $30 \mathrm{~m}$ in height, that overtopped its terminal and westernmost lateral moraine in the form of a hyper-concentrated slurry of silty sediment (Fig. 12e; Table 1, sample 2), thereby allowing flood water to enter adjacent glacier basins (Table 1, samples 2 and 3). Field investigations confirmed that when the floodwater overtopped Langmale glacial lake's western lateral moraine and entered the adjacent debriscovered glacier basin, a second and much smaller flood was triggered from a large meltwater pond. The floodwater proceeded to cascade down a 200-m rock wall into the channel below, where the combined torrents (see dual peak in discharge of cross section D; Fig. 10) entrained more material and debris before merging with the Lower Barun glacial lake outlet stream below the settlement of Riphuk. Boulders, sediment, and uprooted trees were strewn along the length and width of the flood channel from below the settlement of Langmale to Yangle Kharka, with displacement of particularly large boulders ( $>10 \mathrm{~m}$ in diameter) occurring $0.5 \mathrm{~km}$ downstream from a steep section of the Barun river to the vicinity of Nhe Kharka (Fig. 12d).

Massive new canyons and floodplains were created that destroyed dozens of hectares of pasture and forest land (Fig. 13a, b), reportedly killing at least 24 yaks and $d z o$ (yak-cattle crossbreed). The flood channel cross sections were erratic near the source of the flood and became more uniform as the flood moved downstream (Figs. 6 and 13c).

Eyewitnesses of the flood at Yangle Kharka reported hearing a very loud noise sometime in the early afternoon, described variously as "like an avalanche," "loud roar," or "helicopter," followed by a huge cloud of dust (Dorje Sherpa, pers. comm. 2017; Carpenter 2017). The dust cloud was accompanied by high winds at least as far as Riphuk, as villagers reported that trees there had been blown down by hurricane force winds (Carpenter 2017). At Yangle Kharka, a large flood of water, sediment, and trees then descended the river at around 2:30 p.m. Although considerable differences exist between informant accounts for the actual times of the two rock avalanches, arrival of the flood at Yangle Kharka, and other phenomena, those reported here are considered to be reasonably accurate based upon the flood's arrival at Barun Bazaar at 4:00 p.m.

Fortunately, no one in either the Barun or Arun basins was killed or injured. Tourist lodges at Langmale, Zak Kharka, Riphuk Kharka, and Tematang escaped major damage. Yangle Kharka, however, suffered the loss of many hectares of valuable grazing land because of flood deposits of coarse sand and debris (Table 1, sample 5). Four structures were also destroyed, including the Makalu-Barun Hotel, an event that was dramatically captured in a video (https://www.youtube.com/watch? $=2 \mathrm{VB} 1 \mathrm{PRgb}$ Ic) (Fig. 13b). Six bridges between Tematang and Langmale were also washed away, and villagers were deeply concerned that the coming tourist, pilgrimage, and yartsa gunbu (the highly valuable medicinal fungi Ophiocordyceps sinensis) harvesting seasons would be 

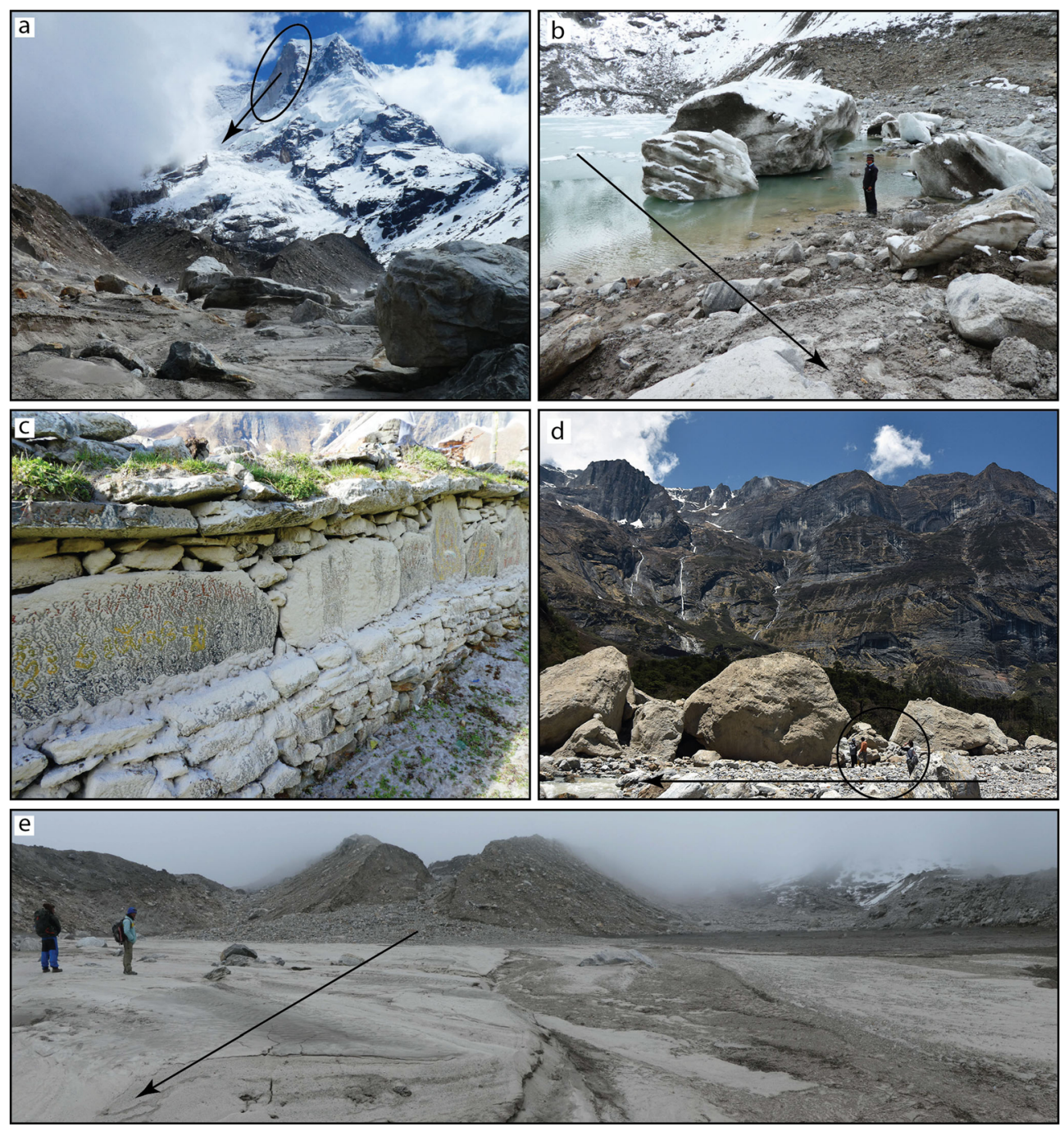

Fig. 12 a The rock face that fell from the upper slopes of Saldim Peak and newly deposited boulders in the foreground below the dam breach. $\mathbf{b}$ The large ice blocks from the avalanche that were deposited in the remains of Langmale glacial lake. $\mathbf{c}$ Sandy deposits from pulverized rock that settled over all surfaces for several kilometers. $\mathbf{d}$ The 10+-m-diameter boulders that were deposited by the flood near Nhe Kharka (photograph by C. Carpenter). e The lakebed sediment and debris that covered the basin below the Langmale terminal moraine as well as the basins to the west and east. The arrow in a shows the direction of rockfall from the west face of Saldim Peak; and arrows in $\mathbf{b}, \mathbf{d}$, and e show the direction of water flow (all photographs by A. Byers except for photograph $\mathbf{d}$ )

negatively impacted because of the damaged or destroyed trails, bridges, and dramatically altered landscapes.

The eyewitness video showed that the color of the debris-laden flood water was dark gray-brown, in contrast to the milky bluepale tan color from suspended silt observed by the authors during the 2014 monsoon high flows (Byers et al. 2014). No reports of unusual smells were given, such as the "earthy" odor reported for the Dig Tsho GLOF in 1985 (Vuichard and Zimmermann 1987) or "gunpowder" smell reported for the Tam Pokhari GLOF in 1998 (Pasang Sherpa, pers. comm. 2009).

\section{Discussion}

Remote sensing, field measurements, numerical modeling, oral testimony, and video footage were used to reconstruct the most likely series of events that led to the April 27, 2017 GLOF in the Barun valley. Methods and results were mutually supportive and demonstrate the importance of combining field observations with numerical modeling in the assessment of glacier hazards. The Langmale GLOF experience also demonstrates the need to conduct field-based GLOF analyses as soon as possible after the event; otherwise, valuable evidence may be lost and the complexity of the event misunderstood or misinterpreted. Clues to the sequence of triggering events and impacts, such as high water marks, airborne deposits, blocks of ice within the remaining and drained lakebed, flood deposits, and eyewitness recollections, are ephemeral. Even with these observations, reconstructing the entire GLOF process chain is a complex task that has many uncertainties including the size and material composition of the mass entering the lake, the bathymetry of the lake, and the grain size distribution of the moraine. Future work should consider using two-phase flow models for the mass entering the lake (e.g., Pudasaini 2014; Mergili et al. 2017) and perform more detailed investigations of the moraine material. Additionally, further research is needed regarding the role of supplementary flood water from englacial conduits 


\section{Original Paper}
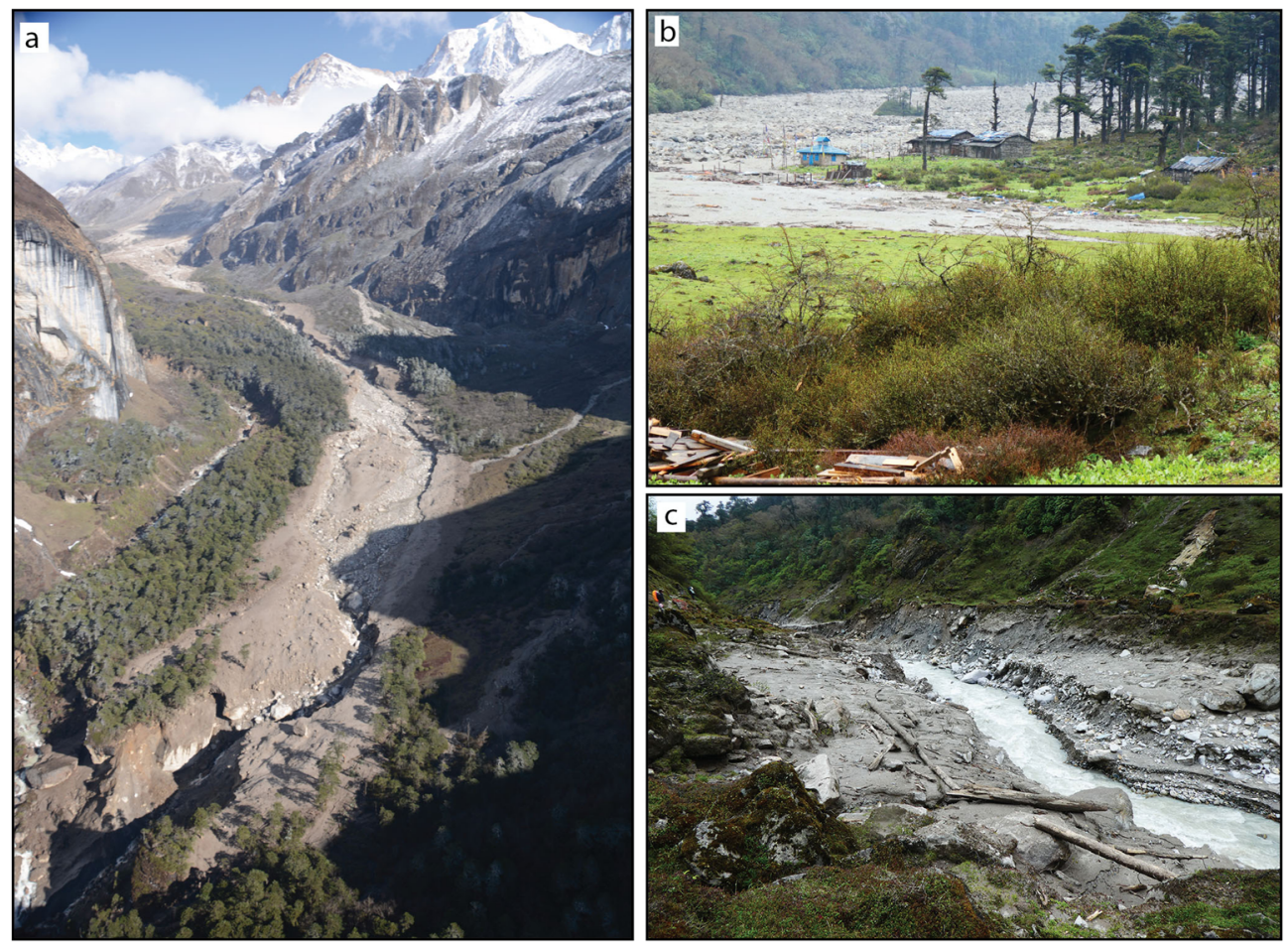

Fig. 13 a The flood path from the air. b The destruction at Yangle Kharka, where four buildings were destroyed. $\mathbf{c}$ The narrowed flood channel below Yangle Kharka

(Benn et al. 2012; Rounce et al. 2017b) and melting caused by friction during the avalanche to overall flood volume.

Old flood scars, levees, and even aged stands of fir trees (Abies spectabilis) in the riparian zone suggest that there have been at least two GLOF events in the Barun valley over the past 100 years, possibly more (Byers et al. 2014; USAID 2014). The recent study of GLOF risk by Rounce et al. (2017a) found that out of Nepal's 131 lakes greater than $0.1 \mathrm{~km}^{2}$, 11 were classified as very high risk, 31 as high risk, 84 as moderate risk, and 5 as low risk (Rounce et al. 2017a). Risk was classified as the combination of hazard and downstream impacts, which considered mass movement entering the lake, moraine steepness, and the presence of an ice-cored moraine in addition to potential hydropower systems, buildings, bridges, and agricultural land that could be impacted by an outburst flood. Langmale glacial lake was excluded from this hazard assessment, since the lake area was less than $0.1 \mathrm{~km}^{2}$. The GLOF that occurred at Langmale glacial lake, however, suggests that the minimum threshold of $0.1 \mathrm{~km}^{2}$ used by Rounce et al. (2017a) should be reduced, since smaller lakes can cause a GLOF that has significant downstream impacts. The classification of very high hazard and the assessment's ability to capture the rockfall from Saldim Peak suggest that the mass movement trajectories are reasonable. The assessment estimated the potential flood volume to be $1.1 \times 10^{6} \mathrm{~m}^{3}$, which is quite close to the estimated flood volume of $1.3 \times 10^{6} \mathrm{~m}^{3}$. However, a $2-\mathrm{D}$ numerical model like BASEMENT should be used for any hazard or risk mitigation efforts. BASEMENT was shown to reproduce the GLOF wave heights, discharge, and flood path well given reasonable estimates of the total mass entering the lake and the morphology of the area.

Although floods such as the Langmale GLOF are not predictable, major damage to infrastructure can be mitigated to some extent by restricting building zones to locations out of floodplains (e.g., Yangle Kharka), well away from torrents debouching from glacial basins, and beyond other indicators of recent hydrologic/ geomorphic activity. Likewise, based upon assessments of the timing of climate forcing, and lag times in glacier recession, lake formation and moraine dam failure, it has been suggested that an increase in GLOF frequencies can be expected during the next decade and into the twenty-second century (Harrison et al. 2018). New adaptive measures will be required in order to minimize the damage and loss of life that these floods may produce. Major infrastructure initiatives, such as large hydropower projects, need to recognize and plan for these events, which to date has been absent from most hydropower feasibility studies in Nepal (Butler and Rest 2017; USAID 2014). Likewise, risk awareness, disaster management, and early warning system training will be of critical importance to the lives and livelihoods of people living in villages and cities (e.g., Pokhara) located downstream of high mountain glaciated landscapes.

The impacts of the 2017 Langmale flood on local economies are uncertain. The flood is of note not only because of its unusual and complex triggering mechanisms (c.f. Kershaw et al. 2005) but also because it "impacted an area of recognized beauty, biological diversity, and cultural significance" (Carpenter 2017; see also: HMG 1990) where local economies have been supplemented for decades by adventure tourists, pilgrims visiting sacred sites, and more recently by yartsa gunbu collectors (Byers et al. 2014). Based upon observations of the climatically similar Hinku Khola river valley below the village of Khote, which experienced a major GLOF from the Tama Pokhari glacial lake in 1998 (Osti et al. 2011; Lamsal et al. 2015), it will take about 15 years for the scoured boulders and river banks of the Barun's riparian zone to re-establish pioneer 
vegetation such as mosses, which in turn will allow for the establishment of fir, birch, rhododendron, and other seedlings. Trekking tourism may experience temporary adverse impacts while lodges, trails, and bridges are rebuilt. Mountaineering will probably not be impacted, as most expeditions currently helicopter in and out of the Makalu basecamp. Likewise, yartsa gunbu collection will likely continue without interruption, as the major harvesting sites are on high alpine ridges well out of the flood path. Reconstruction of bridges destroyed by the flood had already commenced in May 2017, and three new bridges were completed in October 2017. However, local people's enhanced fears of an even more devastating flood from the Lower Barun glacial lake, which was classified by Rounce et al. (2017a) as a high risk, have clearly been heightened. Lower Barun has been growing rapidly and nonlinearly in recent decades, reaching $1.8 \mathrm{~km}^{2}$ in 2017 (Haritashya et al. 2018).

\section{Conclusion}

The series of events leading to the April 20, 2017 GLOF from Langmale glacial lake were reconstructed using remote sensing, field measurements, flood modeling, oral testimony, and video footage. Results collectively suggest that the primary flood trigger was a massive rockfall from the northwest face of Saldim Peak $(6388 \mathrm{~m})$, which plummeted $1200 \mathrm{~m}$ down to Langmale glacial lake. The rockfall caused a massive blast upon contact with the glacier below, which generated a dust cloud and hurricane force winds, and enabled the rockfall to pick up ice blocks during its descent into the lake. The mass movement into the lake, and resultant tsunami-like surge wave that overtopped the terminal and left lateral moraines, triggered the release of a hyperconcentrated flood of sediment, trees, and boulders that carved steep canyons and deposited bedload material from below the settlement of Langmale to the settlement at Yangle Kharka. The flood scoured to bedrock the Barun River between Yangle Kharka and Barun Bazaar and caused the formation of a temporary lake that was reportedly $2-3 \mathrm{~km}$ long at the confluence with Arun River. Fortunately, the lake spontaneously drained the following day, thereby limiting the damage from the GLOF to the buildings, agricultural land, and bridges that were impacted by the initial event. Peak discharge of the GLOF was estimated at $4400 \pm$ $1800 \mathrm{~m}^{3} \mathrm{~s}^{-1}$, and total flood volume was estimated at $1.3 \times 10^{6} \mathrm{~m}^{3}$, suggesting that the flood water was a combination of lake water, snow and ice meltwater, water released from englacial conduits within the debris-covered glacier adjacent to Langmale glacial lake, water generated by friction during the rockfall/ice avalanche, and material (trees, boulders, sediment) scoured by the flood downstream. Numerical modeling of the GLOF confirmed many of these findings, highlighting its importance in a comprehensive plan for hazard and risk mitigation work. In fact, the mass movement trajectories showed that Langmale glacial lake was susceptible to both avalanches and rockfalls entering the lake. The combination of the hazard and the downstream impacts indicates that Langmale glacial lake was a very high risk for a GLOF; that the minimum threshold of $0.1 \mathrm{~km}^{2}$ used by Rounce et al. (2017a) should be reduced, since smaller lakes can cause a GLOF that has significant downstream impacts; and that future work should focus on improving our understanding of the various sources of flood water generated during a GLOF. Finally, the study highlights the importance of conducting timely and integrated field studies immediately following a catastrophic event in order to better understand the complexity of their triggering mechanisms, resultant impacts, and risk reduction management options.

\section{Acknowledgements}

The authors acknowledge the support of the National Science Foundation Dynamics of Coupled Natural and Human Systems (NSF-CNH) Program (award no. 1516912) for the support of Alton Byers and the NASA High Mountain Asia program (award nos. $\mathrm{NNX}_{17} \mathrm{AB}_{27} \mathrm{G}$ and $\mathrm{NNX} 16 \mathrm{AQ} 62 \mathrm{G}$ ) for the support of David Rounce and Dan Shugar, respectively. The DigitalGlobe Foundation (www.digitalglobefoundation.org) and Planet Education and Research Program (www.planet.com) are thanked for providing the satellite imagery used in the study. Ms. Sabina Devkota, Nepal Agricultural Research Council, is thanked for conducting the soil texture analyses. Himalayan Research Expeditions (P) Ltd. provided logistical support for the fieldwork.

Open Access This article is distributed under the terms of the Creative Commons Attribution 4.0 International License (http:// creativecommons.org/licenses/by/4.o/), which permits unrestricted use, distribution, and reproduction in any medium, provided you give appropriate credit to the original author(s) and the source, provide a link to the Creative Commons license, and indicate if changes were made.

\section{References}

U.S. Department of Agriculture (USDA) (2014) Soil survey field and laboratory methods manual, Soil Survey Investigations report no. 51, Version 2. Natural Resources Conservation Service, Lincoln, pp 61-69 https://www.nrcs.usda.gov/Internet/ FSE_DOCUMENTS/stelprdb1244466.pdf

ASTER GDEM Validation Team (2011) ASTER Global Digital Elevation Model version 2 summary of validation results. Available online: https://pdaacaster.cr.usgs.gov/GDEM/ Summary_GDEM2_validation_report_final.pdf Accessed 1 February 2015

Benn D, Bolch T, Hands K, Gulley J, Luckman A, Nicholson L, Quincy D, Thompson S, Tourni R, Wiseman S (2012) Response of debris-covered glaciers in the Mount Everest region to recent warming and implications for outburst floods. Earth-Sci Rev 114:156-174. https://doi.org/10.1016/j.earscirev.2012.03.008

Bricker J, Schwanghart W, Adhikari BR, Moriguchi S, Roeber V, Giri S (2017) Performance of models for flash flood warning and hazard assessment: the 2015 Kali Gandaki landslide dam breach in Nepal. Mt Res Dev 37(1):5-15. https://doi.org/10.1659/MRDJOURNAL-D-16-00043.1

Butler C, Rest M (2017) Calculating risk, denying uncertainty: seismicity and hydropower development in Nepal. Himalaya 37:15-25

Byers A (2017) High water: scientists trace the origin of the damming of the Arun River in April to a bursting glacial lake near Mt. Makalu. Nepali Times July 27, 2017 https:// nepalitimes.atavist.com/high-water]\https://nepalitimes.atavist.com/high-water. Accessed 27 July 2017

Byers A, Byers E, Thapa D (2014) Conservation and restoration of alpine ecosystems in the upper Barun valley, Makalu-Barun National Park, Nepal. Final report, National Geographic Society, Conservation Trust Grant C259-13. Report. National Geographic Society, Washington, DC, pp 76

Byers A, Byers E, McKinney D, Rounce D (2017) A field-based study of impacts of the 2015 earthquake on potentially dangerous glacial lakes in Nepal. Himalaya 37:26-41 Carpenter C (2017) Barun valley glacial lake outburst flood, April 20, 2017. The SubHimalayan, May 2017 http://www.subhimalayan.com/?p=437. Accessed 15 August 2017

Cenderelli D, Wohl E (2001) Peak discharge estimates of glacial-lake outburst floods and "normal" climatic floods in the Mount Everest region, Nepal. Geomorphology 40:5790. https://doi.org/10.1016/S0169-555X(01)00037-X

Chaudhary A (2013) Glacial lake outburst flood frequency analysis in the Sapta Koshi River Basin of Nepal. Thesis project: Asian University for Women, http:// www.auw.edu.bd/library/auwspace/handle/1/22 
Cook S, Quincy D (2015) Estimating the volume of alpine glacial lakes. Earth Surf Dyn 3:559-575. https://doi.org/10.5194/esurf-3-559-2015

Costa J, Schuster R (1998) The formation and failure of natural dams. Geol Soc Am Bull 100:1054-1068

Dwivedi SK, Acharya MD, Simard R (2000) The Tam Pokhari Glacier Lake outburst flood of 3 September 1998. Journal of Nepal Geological Society 22:539-546

Emmer A, Cochachin A (2013) The causes and mechanisms of moraine-dammed lake failures in the Cordillera Blanca, North American Cordillera and Himalaya. AUC Geogr 48:5-15

Falatkova K (2016) Temporal analysis of GLOFs in high-mountain regions of Asia and assessment of their causes. AUC Geogr 51:145-154

Fujita K, Sakai A, Takenaka S, Nuimura T, Surazakov AB, Sawagaki T, Yamanokuchi T (2012) Potential flood volume of Himalayan glacial lakes. Nat Hazards Earth Syst Sci 13:1827-1839. https://doi.org/10.5194/nhess-13-1827-2013

Glacier Hub (2017) A visit to the source of a recent flood in Nepal. http://glacierhub.org/ 2017/05/17/a-visit-to-the-source-of-a-recent-glacier-flood-in-nepal/. Accessed 17 May 2017

Grant GE (1997) Critical flow constrains flow hydraulics in mobile-bed streams: a new hypothesis. Water Resour Res 33:349-358

Hambrey MJ, Quincey DJ, Glasser NF, Reynolds JM, Richardson SJ, Clemmens S (2008) Sedimentological, geomorphological and dynamic context of debris-mantled glaciers, Mount Everest (Sagarmatha) region, Nepal. Quat Sci Rev 27:2361-2389. https:// doi.org/10.1016/j.quascirev.2008.08.010

Haritashya UK, Kargel JS, Shugar DH, Leonard GJ, Strattman K, Watson CS, Shean D, Harrison D, Mandli KT, Regmi D (2018) Evolution and controls of large glacial lakes in the Nepal Himalaya. Remote Sens 10:798

Harrison S, Kargel JS, Huggel C, Reynolds J, Shugar DH, Betts R, Emmer A, Glasser N, Haritashya UK, Klimeš J, Reinhardt L, Schaub Y, Wiltshire A, Regmi D, Vilímek V (2018) Climate change and the global pattern of moraine dammed glacial lake outburst floods. Cryopshere 12:1195-1209. https://doi.org/10.5194/tc-12-1195-2018

Heller V, Hager W, Minor HE (2009) Landslide generated impulse waves in reservoirs: basics and computation. Laboratory of Hydraulics, Hydrology, and Glaciology, ETH Zürich $172 \mathrm{pp}$

His Majesty's Government of Nepal (HMG) and Woodlands Mountain Institute (1990) Makalu-Barun national park and conservation area management plan. His Majesty's Government of Nepal, Kathmandu, Kathmandu

ICIMOD (2011) Glacial lakes and glacial lake outburst floods in Nepal. Report. International Centre for Integrated Mountain Studies (ICIMOD), Kathmandu 96 pp

Jarrett RD (1984) Hydraulics of high-gradient streams. J Hydraul Eng 110:1519-1939

Jarrett RD (2008) Paleoflood research to improve flood science. 2008 NRP Lecture Series for USGS WSC Austin, Texas https://tx.usgs.gov/about/Seminars/ Jarrett.insight.paleoflood.Texas.pdf. Accessed 15 August 2017

Jarrett RD (2016) Summary of peak-discharge computations for the Fall River and Big Thompson River at Estes Park, Colorado, for the September 2013 Flood in the Northern Colorado Front Range. Report to Colorado Water Conservation Board, Denver, $27 \mathrm{pp}$

Jarrett RD, England JF (2002) Reliability of paleostage indicators for paleoflood studies. In: House PK, Webb, RH, Baker, VR, Levish, DR (eds) Ancient floods, modern hazards: principles and applications of paleoflood hydrology, volume 5. AGU Water Science and Application Series, Washington, DC, pp 91-109

Kargel JS (2014) One scientist's search for the causes of the deadly Seti River flash flood. Earth Observatory, January 24, 2014. https://earthobservatory.nasa.gov/blogs/ fromthefield/2014/01/24/setiriverclues/. Accessed 21 April 2017

Kargel JS, Paudel L, Leonard G, Regmi D, Joshi S, Poudel K, Thapa B, Watanabe T, Fort M (2013) Causes and human impacts of the Seti River (Nepal) disaster of 2012. Paper prepared for Glacial Flooding and Disaster Risk Management Knowledge Exchange and Field Training Workshop, Huaraz, Peru, 11-24 July 2013. Huaraz: USAID and The Mountain Institute

Kargel JS, Leonard GJ, Shugar DH, Haritashya UK, Bevington A, Fielding EJ, Fujita K, Geertsema M, Miles ES, Steiner J, Anderson E, Bajracharya S, Bawden GW, Breashears DF, Byers A, Collins B, Dhital MR, Donnellan A, Evans TL, Geai ML, Glasscoe MT, Green D, Gurung DR, Heijenk R, Hilborn A, Hudnut K, Huyck C, Immerzeel WW, Liming J, Jibson R, Kaab A, Khanal NR, Kirschbaum D, Kraaijenbrink PDA, Lamsal D, Shiyin L, Mingyang L, McKinney D, Nahirnick NK, Zhuotong N, Ojha S, Olsenholler J, Painter TH, Pleasants M, Pratima KC, Yuan QI, Raup BH, Regmi D, Rounce DR, Sakai A, Donghui S, Shea JM, Shrestha AB, Shukla A, Stumm D, van der Kooij M, Voss K, Xin W, Weihs B, Wolfe D, Lizong W, Xiaojun Y, Yoder MR, Young N (2016) Geomorphic, tectonic, and geologic controls of geohazards induced by Nepal's 2015 Gorkha Earthquake. Science 351:140. https://doi.org/10.1126/science.aac8353

Kathmandu Post (2017a) Construction of Arun-3 hydro project to begin soon. 2017. http://kathmandupost.ekantipur.com/news/2017-11-23/construction-of-arun-3-hydro-project-to-begin-soon.html. Accessed 15 December 2017
Kathmandu Post (2017b) DPM Nidhi directs concerned bodies to drain water from Arun river. http://kathmandupost.ekantipur.com/news/2017-04-21/dpm-nidhi-directs-concerned-bodies-to-drain-water-from-arun-river.html. Accessed 21 April 2017

Kershaw JA, Clague JJ, Evans SG (2005) Geomorphic and sedimentological signature of a two-phase outburst flood from moraine-dammed Queen Bess Lake, British Columbia. Canada Earth Surf Proc Land 30:1-25. https://doi.org/10.1002/esp.1122

Lala J, Rounce D, McKinney D (2018) Modeling the glacial lake outburst flood process chain in the Nepal Himalaya: reassessing Imja Tsho's Hazard. Hydrol Earth Syst Sci 22:1-17. https://doi.org/10.5194/hess-22-1-2018

Lamsal D, Sawagaki T, Watanabe T, Byers AC, McKinney DC (2015) An assessment of conditions before and after the 1998 Tam Pokhari outburst in the Nepal Himalaya and an evaluation of the future outburst hazard. Hydrol Proc 30:676-691. https://doi.org/10.1002/hyp.10636

Mergili M, Fischer JT, Krenn J, Pudasaini SP (2017) r.avaflow v1, an advanced opensource computational framework for the propagation and interaction of two-phase mass flows. Geosci Model Dev 10:553-569

MyRepublica (2017) Flood debris blocks confluence of Arun and Barun rivers. http:// www.myrepublica.com/news/18603/?categoryld=81. Accessed 21 April 2017

Nie Y, Liu Q, Wang J, Zhang Y, Sheng Y, Liu S (2017) An inventory of historical glacial lake outburst floods in the Himalayas based on remote sensing observations and geomorphological analysis. Geomorphology 308:91-106

Nuimura T, Sakai A, Taniguchi K, Nagai H, Lamsal D, Tsutaki S, Kozawa A, Hoshina Y, Takenaka S, Omiya S, Tsunematsu K, Tshering P, Fujita K (2015) The GAMDAM glacier inventory: a quality controlled inventory of Asian glaciers. Cryosphere 9:849-864

Osti R, Bhattarai T, Miyake K (2011) Causes of catastrophic failure of Tam Pokhari moraine dam in the Mt. Everest region. Nat Hazards 58:1209-1223. https://doi.org/ 10.1007/s11069-011-9723-x

Planet Team (2016) Planet application program interface: in space for life on Earth. San Francisco, CA, https://api.planet.com. Accessed 21 July 2017

Pudasaini S (2014) Dynamics of submarine debris flow and tsunami. Acta Mech 225:2423-2434. https://doi.org/10.1007/s00707-014-1126-0

QGIS Development Team (2016) QGIS geographic information system, Open Source Geospatial Foundation, available at: https://qgis.org/. Accessed 20 June 2018

RGI Consortium (2017) Randolph Glacier Inventory - A dataset of Global Glacier Outlines: Version 6.0: Technical Report, Global Land Ice Measurements from Space, Digital Media, Colorado. https://doi.org/10.7265/N5-RGI-60

Rounce DR, Watson CS, McKinney DC (2017a) Identification of hazard and risk for glacial lakes in the Nepal Himalaya using satellite imagery from 2000-2015. Remote Sens 9:654. https://doi.org/10.3390/rs9070654

Rounce D, Byers AC, Byers EA, McKinney DC (2017b) Brief communications: observations of a glacier outburst flood from Lhotse Glacier, Everest Area, Nepal. Cryosphere 11:443-449. https://doi.org/10.5194/tc-11-443-2017

Schneider D, Huggel C, Cochachin A, Guillén S, García J (2014) Mapping hazards from glacier lake outburst floods based on modeling of process cascades at Lake 513, Carhuaz, Peru. Adv Geosci 35:145-155

Shakya D (2017) Arun displaced urge government for relief. Kathmandu Post, Kathmandu, Nepal. http://kathmandupost.ekantipur.com/news/2017-04-23/arun-displacedurge-government-for-relief.html. Accessed 23 April 2017

Shean D (2017) High Mountain Asia 8-meter DEMs derived from cross-track optical imagery, version 1. [Subset 20150203_0501_104001000742C800_1040010007A71E00]. Boulder, Colorado USA. NASA National Snow and Ice Data Center Distributed Active Archive Center. doi: https://doi.org/10.5067/0MCWJJH5ABYO. Accessed 18 June 2018

Sheftel A, Zembrzycki S (2013) Oral history off the record: toward an ethnography of practice. Palgrave Macmillan, New York, p 293

Somos-Valenzuela M, Chisolm R, Rivas D, Portocarrero C, McKinney D (2016) Modeling a glacial lake outburst flood process chain: the case of Lake Palcacocha and Huaraz, Peru. Hydrol Earth Sys Sci 20:2519-2543

Sosio R, Crosta G, Chen J, Hungr 0 (2012) Modelling rock avalanche propagation onto glaciers. Quat Sci Rev 47:23-40. https://doi.org/10.1016/j.quascirev.2012.05.010

USAID (2014) Affirmative investigations for hydropower projects in Nepal: upper Marsyandi 2, upper Trisuli 1, and Upper Arun. U.S. Agency for International Development's Bureau for Economic Growth, Education and Environment (USAID/E3), Washington DC

Vetsch D, Siviglia A, Ehrbar D, Facchini M, Kammerer S, Koch A, Peter S, Vonwiller L, Gerber M, Volz C, et al (2017) System manuals of BASEMENT, version 2.7. Laboratory of hydraulics, glaciology and hydrology (VAW). ETH Zurich. http:// www.basement.ethz.ch/. Accessed 29 January 2018

Vuichard D, Zimmermann M (1987) The 1985 catastrophic drainage of a moraine-dammed Lake, Khumbu Himal, Nepal: cause and consequences. Mt Res Dev 7(2):91-110

Wang Y, Dong J, Cheng Q (2017) Velocity-dependent frictional weakening of large rock avalanche basal facies: implications for rock avalanche hypermobility? J Geophys Res Solid Earth 122:1648-1676. https://doi.org/10.1002/2016JB013624 
Watson CS, Carrivick J, Quincey D (2015) An improved method to represent DEM uncertainty in glacial lake outburst flood propagation using stochastic simulations. J Hydrol 529:1373-1389

Worni R, Huggel C, Stoffel M (2013) Glacial lakes in the Indian Himalayas-from an areawide glacial lake inventory to an on-site and modeling based risk assessment of critical glacial lakes. Sci Total Environ 468-469:S71-S84

Worni R, Huggel C, Clague JJ, Schaub Y, Stoffel M, (2014) Coupling glacial lake impact, dam breach, and flood processes: A modeling perspective. Geomorphology 224:161176

Electronic supplementary material The online version of this article (https://doi.org/ $10.1007 /$ s10346-018-1079-9) contains supplementary material, which is available to authorized users.

\section{A. C. Byers (-}

Institute of Arctic and Alpine Research (INSTAAR)

University of Colorado at Boulder,

Boulder, CO, USA

Email: alton.byers@colorado.edu

\section{R. Rounce}

Geophysical Institute,

University of Alaska Fairbanks,

Fairbanks, AK, USA

\section{H. Shugar}

Water, Sediment, Hazards, and Earth-surface Dynamics (waterSHED) Lab, University of Calgary,

Calgary, AB, Canada

J. M. Lala

Department of Civil \& Environmental Engineering,

University of Wisconsin - Madison,

Madison, WI, USA

\section{E. A. Byers}

West Virginia Department of Environmental Protection,

Elkins, WV, USA

D. Regmi

Himalayan Research Center,

Kathmandu, Nepal 